\title{
Historyczno-geograficzne podstawy oraz proces kształtowania się regionu łódzkiego
}

\section{Podstawy kształtowania się regionów historycznych w Polsce}

Współczesny region łódzki, utożsamiany z obecnym województwem łódzkim, nie ma wyraźnej, długotrwale ugruntowanej konotacji historycznej, o czym świadczy m.in. brak wyróżniającej go nazwy własnej. Region łódzki różni się znacznie pod względem geograficznym, osadniczym i kulturowym od tradycyjnych regionów (dzielnic Polski), których rodowód sięga wczesnego średniowiecza. Główne regiony historyczne, takie jak Śląsk, Wielkopolska, Pomorze Zachodnie, Małopolska, Mazowsze i Pomorze Wschodnie, dostosowywały się bowiem w procesie swojego rozwoju do zasięgu określonych krain naturalnych i w istocie mają charakter regionów historyczno-geograficznych.

Cechą charakterystyczną tych regionów jest to, że zadziwiająco konsekwentnie "wpisywały” się w określone części dorzecza głównych rzek polskich. I tak Śląsk można utożsamiać z dorzeczem górnej Odry, Wielkopolskę z dorzeczem jej głównego dopływu, czyli Warty, a Pomorze Zachodnie z dorzeczem dolnej Odry i pobrzeżem Bałtyku. W dorzeczu Wisły obserwowaliśmy analogiczną trójdzielność - w górnej jego części ukształtowała się Małopolska, w środkowej Mazowsze, a w dolnej Pomorze Wschodnie/Gdańskie. Nie jest to zbieżność przypadkowa, historycy już od dawna wskazywali na strukturotwórczą rolę rzek w procesie zasiedlania ziem i kształtowania się terytoriów plemiennych, a w konsekwencji regionów historycznych. Schemat tego procesu przedstawiał się z grubsza następująco: pierwsza fala osadnicza trzymała się doliny głównej rzeki, skąd następnie rozprzestrzeniała się w górę jej dopływów coraz to niższego rzędu, by wreszcie wygasnąć w strefie wododziałowej, z reguły 
górskiej lub wyżynnej, gdzie brak już było żyznych dolin, atrakcyjnych dla pierwotnego osadnictwa. Strefy wododziałowe wyznaczały tym samym naturalne ramy regionu, czyli jego granice, pojmowane jednak w kategoriach strefowych.

W efekcie opisanego procesu ukształtował się charakterystyczny model regionu historyczno-geograficznego, którego oś stanowiła rzeka główna, w otoczeniu której ukształtowała się podstawowa strefa osadnicza i gospodarcza regionu. W centralnej jego części, zazwyczaj w dogodnym miejscu przeprawowym, powstawał główny ośrodek krainy, jej stolica, z której, wykorzystując naturalną drożność kolejnych dolin pobocznych, administrowano całym obszarem wpisanym $\mathrm{w}$ dany system dorzecza. Strefy wododziałowe, trudno dostępne, słabiej zasiedlone i bierne ekonomicznie, tworzyły pogranicza międzyplemienne lub międzydzielnicowe.

Już pierwszy rzut oka na mapę ogólnogeograficzną Polski ujawnia, że region łódzki całkowicie nie odpowiada temu wzorcowi regionu historyczno-geograficznego, że jest wręcz jego negatywem. Tutaj bowiem osią regionu nie jest duża rzeka, a wręcz przeciwnie - strefa wzniesień, zwanych „łódzkim półwyspem wyżynnym”, wzdłuż którego przebiega główny na obszarze Polski dział wodny pomiędzy dorzeczami Odry i Wi-

132 sły. Natomiast doliny największych rzek regionu - Warty, Neru, Bzury, Rawki i Pilicy - jakby na zasadzie odwrotności do historycznej zasady kształtowania się regionów, występują na obrzeżach regionu, wyznaczając jego ramy. Są to unikalne cechy geograficzne, które - zdaniem Jana Dylika - stanowią o indywidualności geograficznej regionu łódzkiego w skali Polski.

Andrzej Piskozub uważa, że regiony usadowione „okrakiem” na dziale wodnym, takie jak region bydgoski, łódzki i górnośląski, są tworami świeżej daty i że ich powstanie jest rezultatem swego rodzaju obiektywnej potrzeby wypełnienia luki, jaka, w sensie osadniczym, gospodarczym i polityczno-administracyjnym, wytworzyła się na dalekich peryferiach głównych prowincji historycznych. Wypełnienie tej niszy nową treścią stało się, jego zdaniem, możliwe dopiero w XIX i XX w., kiedy to, za sprawą rodzącego się kapitalizmu przemysłowego, ukształtowały się na tych marginalnych pierwotnie obszarach nowe centra wielkomiejskie - Bydgoszcz, Łódź i Katowice - które podporządkowując sobie otaczającą je przestrzeń, były w stanie wytworzyć nową organizację regionalna, opartą na nowych, przemysłowych więziach, tak odmiennych od tych, jakie spajały stare historyczne prowincje.

Powyższa hipoteza, nosząca znamiona pewnej uniwersalnej prawidłowości, w odniesieniu do regionu łódzkiego nie w pełni się jednak sprawdza. Rzecz w tym, że obecny region nie usadowił się "okrakiem” 
Historyczno-geograficzne podstawy oraz proces kształtowania się regionu...

na wododziale Wisły i Odry dopiero w XIX i XX w. i że czynnikiem sprawczym nie był bynajmniej burzliwy rozwój Łodzi. Stało się to dużo wcześniej za sprawą Łęczycy, unikalnie położonej prawie na głównym dziale wodnym, w miejscu przeprawy przez zabagnioną pradolinę Neru-Bzury, która $\mathrm{z}$ racji takiego położenia już we wczesnym średniowieczu rozciągnęła swoje władztwo szeroko poza obie strony strefy wododziałowej.

\section{Ziemia łęczycka, protoplasta regionu we wczesnym średniowieczu}

Ziemia łęczycka była $\mathrm{w}$ istocie historycznym protoplastą regionu łódzkiego, pokrywając przeważającą część jego obecnego obszaru. Wiadomo, że już u zarania udokumentowanych dziejów tej ziemi rozciągała się ona, począwszy od terenów położonych 20-30 km po zachodniej stronie Warty, poprzez jej całe prawobrzeżne dorzecze, a następnie, po przekroczeniu głównego działu wodnego, wkraczała w dorzecze Pilicy, sięgając maksymalnie aż do $50 \mathrm{~km}$ po wschodniej stronie tej rzeki (ryc. 1). Taki zasięg geograficzny łęczyckiego był absolutnym ewenementem w ówczesnej strukturze geograficzno-terytorialnej ziem polskich i wywołuje pytanie, jak mógł się on kształtować. Zdaniem Dylika, ten rozległy obszar był we wczesnym średniowieczu nierównomiernie zasiedlony, w formie izolowanych od siebie skupień grodów i osad otwartych. Największe skupisko osadnicze występowało wokół istniejącego już od około połowy VI w. grodu w Tumie pod Łęczyca, kolejne wokół równie starego grodu w Mnichowie w dolinie Warty pod Sieradzem, a następne, izolowane od poprzedniego, dalej nad Warta, skupisko w okolicach Spicymierza i Uniejowa. W południowej i wschodniej części omawianego obszaru ważne skupisko związane było z grodem na Górze Chełmo oraz w jej sąsiedztwie między Radomskiem i Przedborzem. Dalsze skupiska występowały w okolicach Rozprzy nad Luciążą i Pilicą oraz w dolinie Wolbórki w okolicach Wolborza. Dylik sugeruje, że - przynajmniej pierwotnie - mogły one stanowić odrębne organizacje opolne, z których później utworzono pierwsze kasztelanie, leżące na dalekich peryferiach państewek plemiennych Polan, Mazowszan i Wiślan. Najstarsze z nich, najludniejsze i zapewne najlepiej zorganizowane, skupienie łęczyckie mogło wykorzystać istnienie tej szczególnej niszy, podporządkować sobie kolejno owe sąsiednie skupiska i stworzyć z tego swoistego pogranicza osobne, zapewne początkowo słabo wewnętrznie zintegrowane, państewko plemienne Łęczycan, które jednak nigdy nie zdołało osiągnąć tej rangi co sąsiednie: Wielkopolska, Mazowsze, Małopolska oraz Śląsk. 
Cechą charakterystyczną regionu historycznego jest posługiwanie się przez jego mieszkańców własnym językiem lub dialektem, ukształtowanym $\mathrm{w}$ czasach wczesnohistorycznych $-\mathrm{w}$ warunkach pewnej izolacji przestrzennej - na bazie kultury plemiennej. Region łódzki nie posiada tej cechy kulturowej, wyróżniającej go spośród innych regionów. Zdaniem Karola Dejny, ludność tego obszaru nie stanowiła bowiem w okresie formowania się dialektów na tyle zwartego, jednolitego i odizolowanego od innych zespołu etnicznego, aby mogła wytworzyć odrębny dialekt. Wprost przeciwnie, specyfika fizjograficzna, a zwłaszcza hydrologiczna naszego regionu sprawiła, że poszczególne jego części podporządkowały się różnym ościennym kręgom dialektycznym, stosownie do przecinających go naturalnych, granicznych stref międzyplemiennych. I tak dział wodny między dorzeczami Bzury i Pilicy, wzdłuż którego rozciągała się niegdyś tzw. puszcza środkowa (jej reliktem jest Puszcza Bolimowska) wyznaczył strefę rozgraniczającą zasięgi występowania dialektów mazowieckiego i małopolskiego. Z kolei południkowo biegnący dział wodny między dorzeczami Pilicy i Warty oraz dawna puszcza łódzka rozgraniczyły dialekty małopolski i wielkopolski. Ten ostatni, ze względu na rozbudowany system dorzecza Warty, dominuje przestrzennie w regionie. Wreszcie na południowo-zachodnich jego krańcach, nad górną Prosna, można odnotować pewne, acz niewielkie, oddziaływanie dialektu śląskiego.

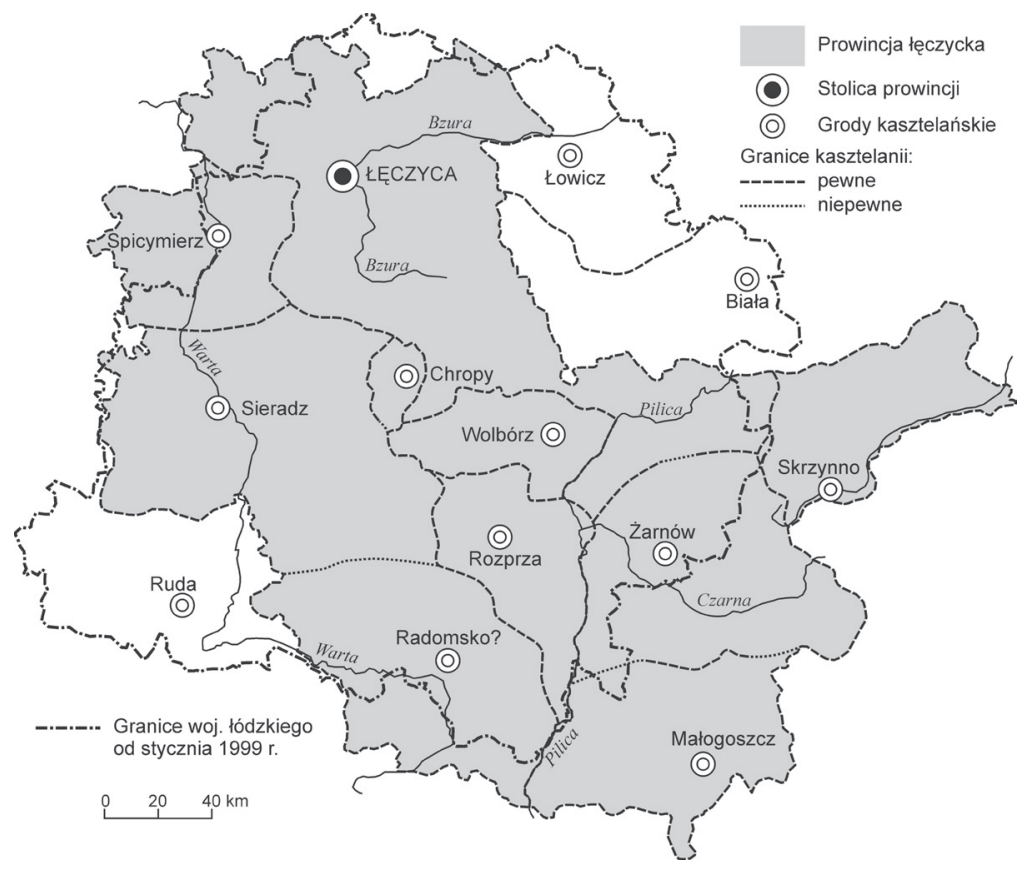

Ryc. 1. Prowincja łęczycka przed okresem rozbicia dzielnicowego 
Przenikanie się $\mathrm{w}$ ciągu ostatnich stuleci fal osadniczych ludności z wymienionych kręgów dialektycznych spowodowało wytworzenie się $\mathrm{w}$ regionie łódzkim, zwłaszcza w jego części centralnej, przejściowych form dialektowych. Paradoksalnie, owo wymieszanie przyniosło bardzo dobre rezultaty, jako że z tego tygla wyłonił się język, który wielu językoznawców uważa za najbardziej zbliżony do ogólnopolskiego wzorca literackiego.

Miejsce "gniazdowej” części naszego regionu, tj. ziemi łęczyckiej, w strukturze prowincji historycznych wczesnośredniowiecznej Polski nie jest jasne. Historycy spekuluja, że u zarania dziejów Słowiańszczyzny na obecnym obszarze Polski była ona terenem kształtowania się samodzielnego terytorium plemiennego, którego mieszkańców określa się umownie - od głównego grodu - mianem Łęczycan. Ich państewko zostało zajęte $\mathrm{w}$ drugiej połowie $\mathrm{X} \mathrm{w}$. przez Polan i wraz z ich państwem stało się trzonem tworzącej się państwowości polskiej. Dylik uważa, że w ramach krystalizującej się organizacji terytorialnej państwa pierwszych Piastów jego władcy utworzyli w drugiej połowie XI w. lub w pierwszej XII w. prowincję łęczycka, wiążącą w jedną całość drobniejsze terytoria wspólnot ponadrodowych, czyli tzw. opola. W ramach nowej organizacji państwa tzw. czoła opolne, wiążące tereny więcej niż jednego opola, stały się ośrodkami władzy królewskiej, sprawowanej przez kasztelanów.

Według bulli gnieźnieńskiej z 1136 r., prowincja łęczycka składała się z ośmiu kasztelanii. Ich położenie miało wyraźny związek z układem sieci rzecznej. Najważniejsza z nich, kasztelania łęczycka, obejmowała pradolinne tereny w dorzeczach Bzury i Neru. W strefie Warty ukształtowały się kasztelanie sieradzka i spicymierska. W dorzeczu Pilicy, po jej zachodniej stronie, nad Wolbórką powstała kasztelania wolborska, a nad Luciążą rozpierska, natomiast po stronie wschodniej w dorzeczu Czarnej kasztelania małogoska jako jedyna wykroczyła poza dorzecza obu głównych rzek prowincji i ukształtowała się w strefie Łośnej i Górnej Nidy. Niektórzy badacze (J. Dylik, R. Rosin) uważaja że oprócz wymienionych musiała istnieć jeszcze jedna kasztelania, nad górną Wartą, gdyż trudno przypuszczać, aby kasztelania sieradzka mogła sięgać aż tak daleko. Umownie określają ją jako kasztelanię radomszczańską; w Wielkim atlasie historycznym z 2002 r. grodem kasztelańskim w tym regionie jest oznaczone Pajęczno. W skład prowincji łęczyckiej nie wchodziła jeszcze kasztelania rudzka, położona nad górną Prosną, która należała wtedy do prowincji kaliskiej. W historiografii Łęczyckiego mówi się ponadto o istnieniu w okolicach Pabianic samodzielnego, niewielkiego opola chropskiego, ale pogląd ten jest ostatnio podważany - uważa się, że termin ten został ukuty a posteriori dla określenia terenów nadanych w 1086 r. przez księżnę Judytę, żonę Władysława Hermana, kapitule krakowskiej. 
Ze względu na swą wczesną przynależność do państwa Polan, prowincję łęczycką traktuje się niekiedy jako pograniczne kresy Wielkopolski i określa mianem Wielkopolski Wschodniej. W rzeczywistości jednak związki Łęczyckiego z Wielkopolską nie zostały dostatecznie silnie utrwalone, a w okresie rozbicia dzielnicowego drogi obu prowincji w znacznej mierze się rozeszły.

Na mocy testamentu Bolesława Krzywoustego z 1138 r., dzielącego Polskę pomiędzy jego synów, Łęczyckie - według różnych poglądów - miało należeć do dzielnicy senioralnej Władysława II bądź stanowić tzw. oprawę wdowią żony Bolesława, księżnej Salomei, bądź też stanowić wyposażenie jego małoletniego syna, Kazimierza, w imieniu którego matka sprawowała przejściowo tutaj władzę.

W dalszej fazie rozbicia dzielnicowego Łęczyckie było terenem licznych walk sukcesyjnych pomiędzy książętami dzielnicowymi i często przechodziło z rąk do rąk. Do ważniejszych wydarzeń, które w istotny sposób wpłynęły na strukturę terytorialno-polityczną regionu, należało opanowanie Łęczyckiego w latach 1229-1231 przez Konrada Mazowieckiego, za rządów którego prowincja zaczęła występować jako księstwo łęczyckie. Kolejną zmianą była utrata przez Konrada trzech kasztelanii zapiliczańskich - żarnowskiej, skrzyńskiej i małogoskiej - które na stałe przeszły do dzielnicy sandomierskiej. Tym samym południowo-wschodnia granica okrojonego Łęczyckiego ustaliła się na środkowym odcinku Pilicy.

Szczególnie brzemienne dla struktury terytorialnej tych ziem wydarzenie nastąpiło w 1263 r., kiedy to, w wyniku ugody kładącej kres waśni pomiędzy Kazimierzem Konradowicem a jego synem Leszkiem Czarnym, dla tego drugiego wykrojone zostało z Łęczyckiego księstwo sieradzkie. Objęło ono przeważająca, południowo-zachodnią część dawnej prowincji, z kasztelaniami: sieradzką, spicymierską, domniemaną radomszczańską, rozpierską oraz częścią wolborskiej. Granice nowego księstwa od strony macierzystego, bardzo pomniejszonego księstwa łowickiego wyznaczyły w głównym przebiegu rzeki Ner oraz Wolbórka. Wysuwany niekiedy, w związku z powstaniem samodzielnego księstwa sieradzkiego, pogląd o istnieniu odrębnego plemienia Sieradzan nie ma, jak to wykazał Stanisław Zajączkowski, żadnych wiarygodnych podstaw źródłowych. Za sprawą następcy Leszka Czarnego, jego przyrodniego brata Władysława Łokietka, który przejął po nim w 1288 r. księstwo sieradzkie, ponadto panował w księstwie brzesko-kujawskim, a później również łęczyckim, ziemie te stały się bazą wyjściową dla procesu scalania ziem polskich. Droga do tego celu była długa i kręta, oba księstwa przeszły nawet czasowo w lenno innych władców - księcia inowrocławskiego oraz księcia dobrzyńskiego - i dopiero po ich śmierci, odpowiednio w 1339 i 1352 r., dostały się pod bezpośrednią władzę króla polskiego, którym był już wtedy Kazimierz Wielki. 


\section{Od zjednoczenia kraju do schyłku Rzeczypospolitej}

Po zjednoczeniu Polski przez Łokietka dawne księstwa zamieniono na ziemie. Większe z nich, nad którymi w imieniu króla władał najważniejszy urzędnik ziemski - wojewoda - otrzymały w XIV w. rangę województw. Natomiast mniejsze jednostki terytorialne, nieposiadające urzędu wojewody, nadal nazywano ziemiami. Stosownie do tego dawne księstwa łęczyckie i sieradzkie, po włączeniu ich w połowie XIV w. do Polski, stały się samodzielnymi województwami (ryc. 2).

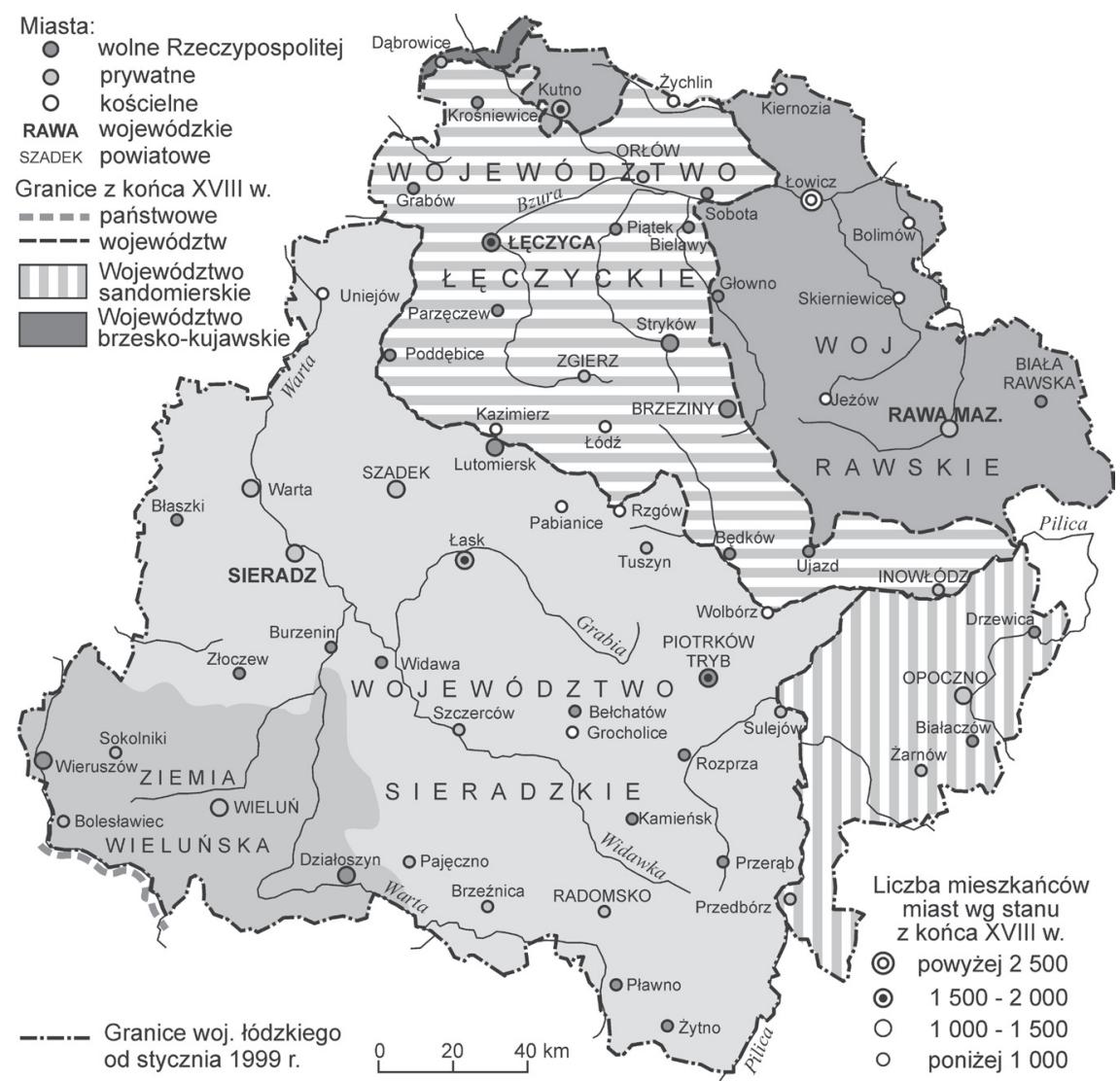

Ryc. 2. Obszar obecnego województwa łódzkiego w podziale administracyjnym Polski w okresie przedrozbiorowym (XIII-XVIII w.)

Inaczej rzecz się natomiast miała z Wieluńskiem. Związki tego terenu z łęczycko-sieradzkim trzonem regionu były świeższej daty, a jego dzieje bardziej złożone. To dawne opole lub państewko plemienne zostało po włączeniu go do państwa pierwszych Piastów przekształcone 
w kasztelanię rudzką. W okresie rozbicia dzielnicowego została ona związana z Wielkopolska, a ściślej z prowincją kaliską. W 1234 r. dostała się z kolei pod panowanie książąt śląskich, którzy ok. 1285 r. przenieśli siedzibę kasztelanii z Rudy do lepiej położonego Wielunia. Po wielu burzliwych zmianach, kasztelania, już wieluńska, przeszła ok. 1329 r. we władanie Łokietka, by w 1370 r. stać się lennem Władysława Opolczyka. Dopiero w 1391 r. odzyskał ją, na drodze zbrojnej, Władysław Jagiełło. Ze względu na skromne rozmiary oraz brak pełnej hierarchii urzędniczej otrzymała wówczas status ziemi, a ok. 1420 r. została podporządkowana wojewodzie sieradzkiemu. Od tej pory Wieluńskie stało się trwale swego rodzaju autonomiczną częścią Sieradzkiego.

O ile Łęczyckie i Sieradzkie przechodziły na ogół wspólne koleje losów, co je w pewien sposób integrowało, o tyle dzieje pozostałych części obecnego regionu łódzkiego kształtowały się zazwyczaj odmiennie. Dawne tereny zapiliczańskie Łęczyckiego, oderwane od niego w 1239 r., związały się na długo z ziemia, a następnie województwem sandomierskim, czyli szeroko pojętą Małopolska, i dopiero w okresie międzywojennym częściowo ponownie zostały połączone z macierzystym regionem. Położone poza wschodnią granicą Łęczyckiego dawne kasztelanie: bialska (od początku XIV w. rawska), łowicka i leżąca dalej na północ gostynińska 138 dzieliły losy Mazowsza, wchodząc w skład ziem rawskiej i sochaczewskiej. W 1313 r. włączono je w skład wydzielonego z Mazowsza księstwa rawskiego, wiodącego, nawet po zjednoczeniu większości ziemi Polski, samodzielny byt, na zasadzie jej terytorium lennego. Dopiero po wygaśnięciu lokalnej linii Piastów mazowieckich, w 1462 r., księstwo rawskie zostało przyłączone do Korony i przekształcone w województwo rawskie. Skrajnie zachodnie fragmenty obecnego regionu łódzkiego, w rejonie Błaszek, aż do czasów najnowszych były natomiast związane z ziemią i województwem kaliskim, a więc stanowiły część historycznej Wielkopolski.

$\mathrm{W}$ połowie XIV w. w miejsce dawnych kasztelanii utworzono - w zmienionym jednak, niekiedy znacznie, układzie terytorialnym - nowe jednostki, tj. powiaty. Powstały one głównie w związku z organizacją sądów ziemskich, ale pełniły też $w$ pewnym sensie funkcje wojskowe oraz samorządowe $-\mathrm{w}$ ośrodkach powiatowych zwoływano m.in. pospolite ruszenie, odbywały się tam sejmiki szlacheckie, dokonywano wyboru posłów. Z powyższych względów siedzibami powiatów mogły być tylko miasta królewskie, nawet jeśli były dużo mniejsze od okolicznych miast prywatnych lub duchownych (stąd powiatowa ranga maleńkiego Orłowa). Stan taki utrzymywał się aż do drugiej połowy XIX w.

Województwo łęczyckie dzieliło się wówczas na trzy powiaty: łęczycki, orłowski i brzeziński. W znacznie większym województwie sieradzkim utworzono cztery powiaty: sieradzki, szadkowski, piotrkow- 
ski i radomskowski. Ziemia wieluńska składała się z dwóch powiatów - wieluńskiego i ostrzeszowskiego, przy czym ten drugi obejmował tylko niewielki skrawek obecnego regionu łódzkiego w rejonie Wieruszowa. Województwo rawskie dzieliło się z kolei na trzy powiaty: rawski, sochaczewski i gostyniński, przy czym dwa ostatnie w niewielkich fragmentach, w okolicach Łowicza oraz Kutna, wkraczały na obszar obecnego regionu. I wreszcie w województwie sandomierskim, w części historycznie związanej z naszym regionem, utworzono powiat opoczyński. Podział ten okazał się niezmiernie trwały i w zasadzie bez zmian przetrwał aż do upadku Rzeczypospolitej, a nawet dłużej, z tym, że powiaty stały się z czasem jednostkami administracji państwowej. Umacnianiu się więzi wewnątrzregionalnych i organizacji przestrzeni w obrębie terytorium łęczycko-sieradzkiego, a także z sąsiednimi ziemiami, sprzyjało zagęszczenie sieci miast i łączącej je infrastruktury drogowej.

Już we wczesnym średniowieczu na interesującym nas obszarze istniało szereg przedlokacyjnych ośrodków o charakterze protomiejskim. Wyrastały one bądź to $z$ zespołów grodowych - pełnych i niepełnych - bądź też, częściej, z osad targowych. Najważniejsze, rzecz jasna, bo pełniące więcej funkcji, były pełne zespoły grodowe. Składały się one z grodu - siedziby władcy (lub możnowładcy) i jego drużyny - rzemieślniczego podgrodzia, a niekiedy także dodatkowego podgrodzia kościelnego oraz targowiska, gdzie dokonywała wymiany handlowej zarówno okoliczna ludność rolnicza, jak i kupcy z innych regionów, a nawet krajów. Taki charakter miały przede wszystkim dawne książęce zespoły grodowe w Łęczycy i Sieradzu. Nieco niższą rangę miały dawne centra kasztelanii - Spicymierz, Ruda, Radomsko, Rozprza, Wolbórz, Żarnów, Skrzynno, Biała i Łowicz, spośród których wyróżniały się Wolbórz, Radomsko, Żarnów i Łowicz, które miały niepełny zespół grodowy - gród i podgrodzie targowe. Do najstarszych ośrodków przedlokacyjnych o charakterze miejskim należy też zaliczyć Inowłódz, Pajęczno, Brzeziny oraz Orłów, które według niektórych źródeł (Miasta polskie w tysiacleciu) miały być również siedzibami kasztelanii. Niekiedy znacznie prężniej od dawnych ośrodków kasztelańskich rozwijały się osady targowe usytuowane w sieci ważniejszych dróg. Zdaniem Mariusza Kuleszy, należały do nich: Bolesławiec, Burzenin, Gorzkowice, Grabów Łęczycki, Kazimierz nad Nerem, Łubnice, Piątek, Piotrków, Sobota, Sulejów, Uniejów i Warta. Spośród miejscowości o innym rodowodzie ważnymi przedlokacyjnymi ośrodkami o charakterze miejskim były: Jeżów, Lutomiersk, Przedbórz i Szadek, a nieco niższej rangi zapewne także Stara Brzeźnica, Grocholice i Działoszyn.

W okresie lokacji miast na prawie niemieckim, począwszy od XIII w., nowe prawa miejskie otrzymały wszystkie dawne ośrodki protomiejskie, a także szereg nowych miejscowości. Pierwszym miastem, które skorzystało 
z nowych przywilejów, już w 1238 r., były Łubnice. Prawdziwy „wysyp” nowych lokacji dokonał się jednak w XIV, a zwłaszcza w XV i XVI w. Spośród niewymienionych dotychczas miejscowości prawa miejskie uzyskały (w porządku alfabetycznym): Białaczów, Bielawy, Błaszki, Bolimów, Bratoszewice, Brzeźnica Nowa, Buczek, Budziszewice, Budzynek, Dmosin, Drzewica, Gieczno, Głowno, Goraj, Kałów, Kamieńsk, Kamion, Kiernozia, Krośniewice, Kutno, Lututów, Łask, Łęgonice, Łódź, Małyń, Mazew, Oporów, Opoczno, Osjaków, Pabianice, Parzęczew, Pławno, Poddębice, Przerąb, Rawa, Rusiec, Rzeczyca, Rzgów, Skierniewice, Skoszewy Stare, Sokolniki, Stryków, Świnice Warckie, Toporów, Tuszyn, Ujazd, Widawa, Wieluń, Wieruszów, Witonia, Zgierz, Złoczew i Żychlin.

Struktura własnościowa owego zbioru miast była złożona. Spośród ogólnej liczby blisko 90 miast 33 stanowiły pierwotnie własność monarszą. Były to: Biała (Rawska), Bolesławiec, Bolimów, Brzeziny, Brzeźnica Stara i Nowa, Budziszewice, Burzenin, Dąbrowice, Inowłódz, Jeżów, Lutomiersk, Łęczyca, Opoczno, Orłów, Pajęczno, Piątek, Piotrków, Przedbórz, Radomsko, Rawa, Rozprza, Ruda, Rzeczyca, Sieradz, Sulejów, Szadek, Tuszyn, Warta, Wieluń, Wolbórz, Zgierz i Żarnów. Miasta monarsze miały z reguły lepsze podstawy rozwoju. Dotyczyło to w szczególności tych o starszym rodowodzie, a ponadto dobrze usytuowanych w sieci dróg 140 o ponadlokalnym, handlowym znaczeniu. Pod tym względem wyróżniała się Łęczyca, która w XVII w. została wyznaczona na jeden z sześciu ośrodków w państwie do wymiany z kupcami zagranicznymi. Dogodne warunki do handlu ponadlokalnego miała też $-\mathrm{z}$ racji swojego pogranicznego sąsiedztwa z księstwami śląskimi - ziemia sieradzka, przez której terytorium pędzono z Rusi i Małopolski bydło rzeźne na Śląsk, a w odwrotnym kierunku przewożono wyroby luksusowe. Wpłynęło to pozytywnie szczególnie na rozwój Wielunia, Sieradza, Pajęczna, Wieruszowa, Bolesławca i Radomska. Większość z tych miast liczyła w drugiej połowie XVI w. po 2-3 tys. mieszkańców - co wówczas było liczbą znaczną - i po 200-300 domów oraz 100-150 rzemieślników różnych zawodów. Oprócz wymienionych, podobną skalę wielkości osiągnęły ponadto Inowłódz, Rawa, Opoczno, Warta, Szadek i Zgierz.

Szczególną karierę - także formalną - odnotował w tym czasie jednak przede wszystkim Piotrków, który swój dynamiczny rozwój zawdzięczał czynnikowi politycznemu. Po unii w Krewie stołeczny Kraków znalazł się mianowicie $\mathrm{w}$ zbyt odległym położeniu od Litwy, toteż dwór królewski często rezydował właśnie w Piotrkowie, skąd było bliżej do Wilna. Od 1442 r. zbierały się tu synody duchowne, a w latach 1493-1567 większość sejmów koronnych. Piotrków dynamicznie się wówczas rozbudowywał i pełnił nieoficjalnie funkcję drugiej stolicy państwa. Miał nawet szanse stać się jego oficjalną stolica, ale w 1526 r., po przyłączeniu do Ko- 
Historyczno-geograficzne podstawy oraz proces kształtowania się regionu...

rony Mazowsza, wybór padł na Warszawę, która miała jeszcze dogodniejsze położenie. W Piotrkowie ulokowano natomiast, w 1578 r., Trybunał Koronny, któremu miasto zawdzięcza swą obecną dumną nazwę - Piotrków Trybunalski.

Własność duchowną stanowiło pierwotnie 11 miast: Kazimierz nad Nerem, Łęgonice, Łowicz, Łódź, Mazew, Pabianice, Rzgów, Skierniewice, Sobota, Świnice Warckie i Uniejów, do których z czasem dołączyło siedem dawnych miast monarszych: Biała, Jeżów, Piątek, Sulejów, Tuszyn, Wolbórz i Żarnów, a także Łubnice i Toporów, które były wcześniej własnością szlachecką. Spośród nich największe znaczenie zyskał Łowicz, w którym - w związku z przeniesieniem stolicy do Warszawy - zwykł się zatrzymywać dwór arcybiskupa gnieźnieńskiego; dawniej, w drodze do Krakowa, rolę taką odgrywał Uniejów. Oprócz nich, większe znaczenia miały także ośrodki dóbr biskupich - Wolbórz i Pabianice - a także cysterski Sulejów.

Pozostałe ponad 40 miast, czyli blisko połowa ogólnej ich liczby, stanowiły własność rycerska/szlachecką. W porównaniu z poprzednimi były to $\mathrm{z}$ reguły bardzo małe miasteczka, pełniące funkcję ośrodków obsługi lokalnych dóbr.

Niektóre z wymienionych wcześniej miejscowości, zwłaszcza te mniej korzystnie położone, nigdy w ogóle nie wykorzystały otrzymanych praw miejskich, a w innych, w krótszym lub dłuższym czasie, lokacja okazywała się nieudana i wracały do rangi wsi, toteż w przypadku wielu z nich aż trudno uwierzyć w jakiekolwiek ich miejskie dziedzictwo. Dotyczyło to w szczególności miast prywatnych, powoływanych często do tej rangi tylko za sprawą ambicji ich właścicieli, bez uwzględniania realiów gospodarczych bądź lokalizacyjnych. Pod tym względem miasta monarsze i duchowne miały znacznie lepsze podstawy rozwoju, choć i wśród nich nie brakowało takich, które funkcjonowały na skraju wegetacji.

Spośród miast prywatnych tylko nieliczne, które były siedzibami co znaczniejszych rodów, uzyskały większe znaczenie w sieci osadniczej regionu. Należały do nich Łask, Widawa, Burzenin, Działoszyn, Poddębice, Lutomiersk, Stryków, Drzewica i parę innych.

Mimo wspomnianych wielu nieudanych lokacji, sieć miejska w naszym regionie i tak była bardzo gęsta. Według Bohdana Baranowskiego, średnia odległość między miastami i miasteczkami wynosiła zaledwie ok. $16 \mathrm{~km}$. Umożliwiało to mieszkańcom nawet najdalej położonych miejscowości dojście pieszo lub dojazd zaprzęgiem w parę wołów owe co najwyżej $8 \mathrm{~km}$ do najbliższego ośrodka miejskiego, załatwienie swoich transakcji kupna-sprzedaży i powrót do domu przed nocą.

Lata zamętów wojennych oraz upadku gospodarczego Rzeczypospolitej w drugiej połowie XVII, a zwłaszcza w XVIII w. przyczyniły się 
do utraty funkcji miejskich przez wiele kolejnych miast. Zniszczenia, grabieże, depopulacja i utrata przez chłopów pańszczyźnianych siły nabywczej spowodowały, że większość miast - a wówczas praktycznie miasteczek - jedynie wegetowała, podlegając stopniowo procesowi agraryzacji, co faktycznie upodabniało je do wsi.

Sytuacja gospodarcza kraju, w tym również naszego regionu, poprawiła się nieco dopiero w ostatnim ćwierćwieczu XVIII w. O ile nie wpłynęła ona w zasadzie na rozwój sieci miast, o tyle w znaczący sposób przyczyniła się do zagęszczenia się sieci osiedli wiejskich. Stało się to za sprawą tzw. kolonizacji olęderskiej, wzorowanej na wcześniejszej kolonizacji mennonickich osadników holenderskich na Żuławach i nad dolną Wisłą z tą różnica, że na naszym terenie osadnicy wywodzili się głównie z krajów niemieckich. Kolonizacja olęderska przyczyniła się do zagospodarowania niedostępnych wcześniej dla rolnictwa terenów podmokłych dolin i bezodpływowych mokradeł, które dzięki melioracji stały się produktywne. W ten sposób, m.in. na niskiej terasie doliny Warty w Sieradzu, powstały Holendry Małe i Holendry Duże. „Olędrzy” zagospodarowywali również nieużytki i uroczyska leśne. Przykładem mogą być wyrosłe wśród lasów na obecnym obszarze Łodzi Holendry Kałowskie (Grabieniec), Holendry Radogoskie (Żabieniec), Holendry Stokowskie (Antoniew) i szereg innych.

Nowa kolonizacja przyczyniła się do zróżnicowania społeczności regionu nie tylko pod względem etnicznym i religijnym (osadnicy niemieccy byli w większości protestantami), lecz także pod względem społecznym. Koloniści otrzymywali bowiem spore nadziały ziemi, nie byli też zobowiązani do odrabiania pańszczyzny, a jedynie płacili czynsz, w związku z czym ich efektywność ekonomiczna była większa niż w sąsiednich wsiach pańszczyźnianych. Pod ich wpływem również w tych ostatnich zaczęła się upowszechniać zamiana robocizny na opłaty pieniężne, co sprzyjało ożywieniu wymiany handlowej między miastem a wsią.

Nowa kolonizacja przyczyniła się ponadto do pozytywnych zmian w strukturze gospodarczej regionu, gdyż nierzadko towarzyszył jej rozwój nowych form produkcji protoprzemysłowej. Obok wielu osad olęderskich powstawały huty szkła, wykorzystujące lokalne pokłady piasku oraz drewno z pobliskich lasów. Tylko na obszarze obecnej Łodzi powstało szereg takich hut: Huta Chojeńska, Huta Rogowska, Huta Radogoska, Huta Sokołowska i inne. Zaczęło się też upowszechniać sukiennictwo, na rzekach wznoszono folusze, nowe młyny oraz tartaki. Specyficzną formą osadnictwa protoprzemysłowego były ponadto, tworzone $\mathrm{w}$ tym samym czasie, drobne osady śródleśne typu "budy", wyspecjalizowane w pozyskiwaniu i przetwarzaniu produktów leśnych. Były więc budy węglarzy, smolarzy, potażników, bednarzy i innych. Wszystkie te formy pierwotnego uprzemysłowienia wywarły pewien wpływ na późniejsze decyzje industrializacyjne, głównie w centralnej części regionu. 
Historyczno-geograficzne podstawy oraz proces kształtowania się regionu...

\section{Okres zaboru pruskiego}

Pierwszy rozbiór Polski nie naruszył struktury terytorialnej ziem wchodzących w skład obecnego regionu łódzkiego. Natomiast w wyniku drugiego rozbioru, w 1793 r., przeważająca jego część, w granicach ziem: łęczyckiej, sieradzkiej i rawskiej, znalazła się pod zaborem pruskim, a jedynie tereny zapiliczańskie pozostały jeszcze, na krótko, w obrębie okrojonej Rzeczypospolitej. Tym samym Pilica stała się rzeką graniczną oddzielającą dwa państwa.

Zaanektowane tereny zostały włączone w skład nowo utworzonej prowincji o nazwie Prusy Południowe i zaliczone do departamentu łęczyckiego, przekształconego wkrótce $\mathrm{w}$ departament piotrkowski, gdy okazało się, że Piotrków jest lepiej wyposażony w odpowiednie obiekty publiczne od stagnującej dawnej stolicy ziem.

Po trzecim rozbiorze Polski Pilica utrwaliła swoją funkcję rzeki granicznej, oddzielając tym razem od siebie nowo zagarnięte ziemie cesarstwa pruskiego i cesarstwa austriackiego. Tereny zapiliczańskie weszły wówczas w skład tzw. Galicji Zachodniej, w ramach której wydzielono m.in. powiat opoczyński.

W 1796 r. pruską część naszego regionu podzielono pomiędzy nowe departamenty. Ziemie rawska i łęczycka znalazły się $\mathrm{w}$ departamencie warszawskim, natomiast ziemia sieradzka z wieluńską w departamencie kaliskim. Tym samym po raz pierwszy doszło do istotnego rozdzielenia "gniazdowych ziem" naszego regionu, łączącego pierwsze z Mazowszem, a drugie $z$ Wielkopolską. W ramach departamentu warszawskiego wydzielono m.in. powiaty: łęczycki, zgierski, brzeziński, orłowski (z siedzibą w Kutnie) i rawski; ponadto obrzeżna część terenów obecnego regionu weszła w skład powiatów sochaczewskiego i gostynińskiego. W departamencie kaliskim z kolei utworzono m.in. powiaty: warcki, szadecki, sieradzki, piotrkowski, radomszczański i wieluński oraz ostrzeszowski, w skład którego weszły okolice Wieruszowa. Była to więc struktura terytorialna zbliżona do staropolskiej, wzbogacona jedynie o dwie nowo utworzone jednostki - powiaty zgierski i warcki.

Okres rządów pruskich (1793-1807) przyczynił się do dalszego wzbogacenia wiejskiej sieci osadniczej regionu. Stało się to za sprawą kolonizacji fryderycjańskiej, prowadzonej na terenach zagarniętych przez kamerę pruską dawnych dóbr królewskich oraz przejętych przez nią w 1796 r., w wyniku sekularyzacji, dóbr duchowych. W ręce państwa pruskiego przeszły wtedy m.in. duże włości biskupie wokół Łowicza, Skierniewic, Wolborza, Pabianic i Łodzi, wraz z tymi miastami, jak również takie dawne miasta duchowne, jak Grocholice, Jeżów, Łęgonice, Piątek, Rzgów, Sulejów, Uniejów i inne. 
Kolonizacja fryderycjańska, podobnie jak olęderska, objęła przede wszystkim różne uroczyska, pustaci, tereny podmokłe i obszary leśne. Kolonie te były również oczynszowane i także miały kształt wsi luźno skupionych, najczęściej regularnych rzędówek. Szczególnie wiele nowych kolonii pruskich powstało na słabo dotychczas zasiedlonych terenach tzw. puszczy łódzkiej. W obrębie dawnych łódzkich dóbr biskupów kujawskich utworzono np. kolonie Augustów oraz Olechów Duży i Olechów Mały, w byłych pabianickich dobrach kapituły krakowskiej Starową Górę i Chechło, a w monarszym kluczu dóbr wiączyńskich na miejscu starej wsi założono Wiączyń Górny i Wiączyń Dolny oraz charakterystyczną, dużą kolonię Nowosolna o unikatowym w skali kraju, ośmiowektorowym układzie radialnym.

Powstanie kolonii fryderycjańskich przyczyniło się do wzmocnienia żywiołu niemieckiego oraz dychotomii w krajobrazie kulturowym wsi regionu, a także w strukturze etnicznej, religijnej i społecznej ich mieszkańców. Jeżeli do tego dodamy, że w 1802 r. pojawiła się jeszcze jedna grupa mniejszościowa, trudniąca się głównie rękodziełem płócienniczym niewielka wspólnota braci czeskich osiadła w Zelowie, a także uwzględnimy zasiedziałą tu od stuleci mniejszość żydowska, bardzo liczną w miastach, szczególnie mniejszych (np. w Działoszynie, Grabowie, Kamieńsku, Żychlinie i innych stanowili oni ponad połowę mieszkańców), to otrzyma-

144 my obraz wielokulturowego regionu. To wielokulturowe oblicze, znacznie wzmocnione w następnych dekadach, stało się na długo, aż do 1945 r., charakterystyczną „"wizytówką" naszego regionu.

\section{Czasy Księstwa Warszawskiego i Królestwa Polskiego}

W czasach Księstwa Warszawskiego (1807-1815) doszło do istotnych zmian politycznych. Wyzwolenie ziem drugiego i trzeciego zaboru pruskiego, a następnie dołączenie do nich pod władzą polską terenów byłego trzeciego zaboru austriackiego sprawiło, że przestała istnieć granica państwowa na Pilicy. W wewnętrznym podziale ziem obecnego regionu łódzkiego na departamenty i powiaty nie zaszły natomiast żadne zmiany, poza tym, że powiat opoczyński znalazł się w nowo utworzonym departamencie radomskim.

Nastąpiło jednak wówczas pewne ożywienie życia gospodarczego, co istotne $\mathrm{w}$ sferze produkcji przemysłowej. Wyrazem tego było m.in. utworzenie manufaktury sukienniczej w Skierniewicach, a także próba stworzenia ośrodka rękodzieła włókienniczego w Ozorkowie, wówczas jeszcze wsi. Tak zwana umowa ozorkowska, zawarta w 1807 r. przez jej właściciela z osiedlającymi się w niej cudzoziemskimi sukiennikami, stała się później wzorem dla innych osiedli fabrycznych regionu łódzkiego. 
Historyczno-geograficzne podstawy oraz proces kształtowania się regionu...

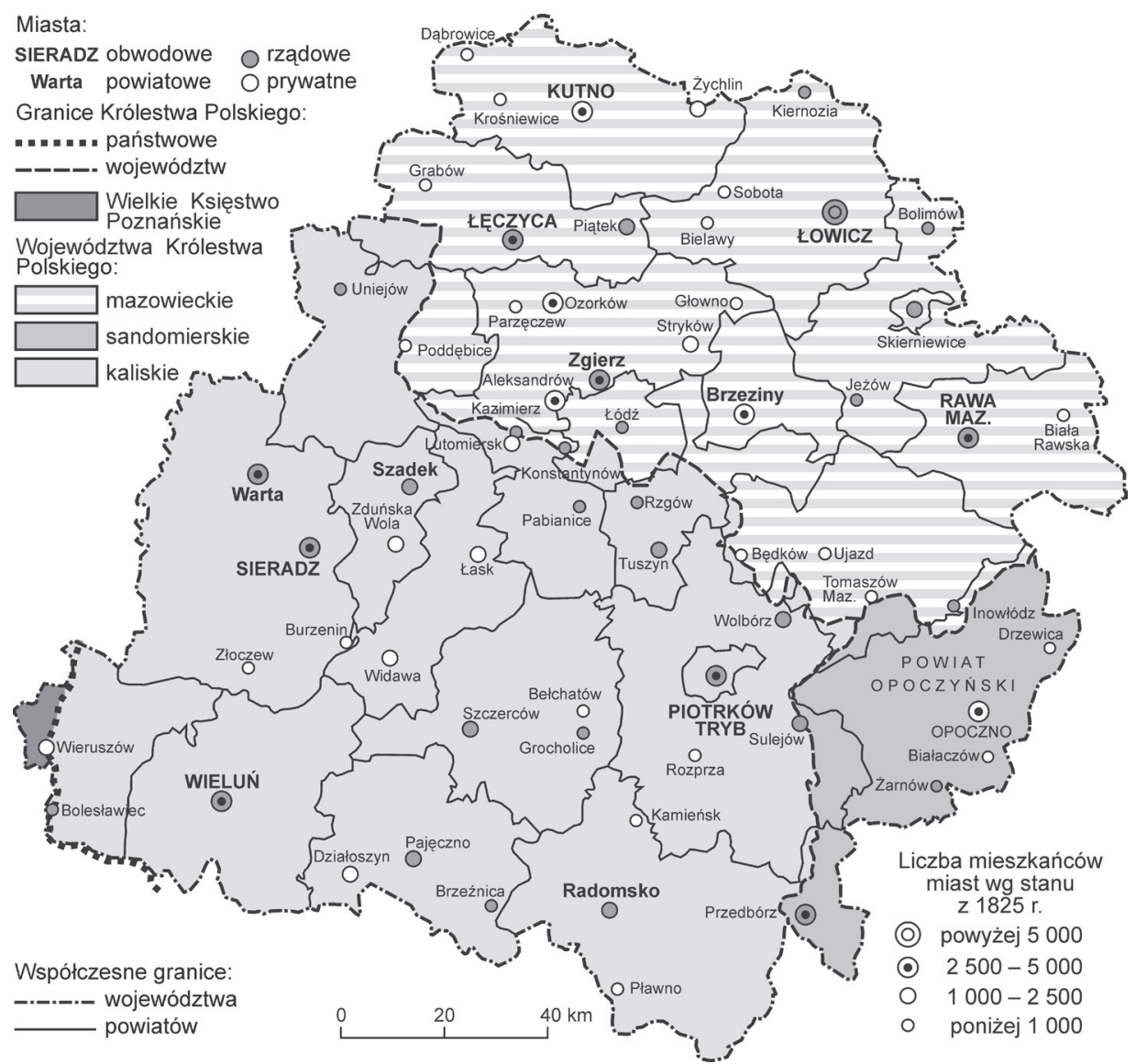

Ryc. 3. Obszar obecnego województwa łódzkiego w podziale administracyjnym Królestwa Polskiego

W kolejnym okresie, po utworzeniu w 1815 r. autonomicznego, w ramach Cesarstwa Rosyjskiego, Królestwa Polskiego, w strukturze administracyjnej ziem obecnego regionu łódzkiego zaszły tylko niewielkie zmiany. Pierwsza, czysto formalna, polegała na przemianowaniu departamentów - mazowieckiego, kaliskiego i radomskiego - ponownie na województwa, bez żadnych wszakże zmian ich granic (ryc. 3). Novum stanowiło natomiast wprowadzenie dwustopniowego podziału ich struktury wewnętrznej. Powołano mianowicie do życia tzw. obwody, łączące w sobie zazwyczaj po dwa powiaty. I tak w województwie mazowieckim utworzono obwód kutnowski z powiatami kutnowskim i gostynińskim, obwód łowicki z powiatami łowickim i sochaczewskim (poza naszym obszarem), łęczycki z powiatami łęczyckim i zgierskim oraz rawski z powiatami rawskim i brzezińskim. W województwie sieradzkim obwód 
sieradzki z powiatami sieradzkim i szadkowskim, obwód piotrkowski z powiatami piotrkowskim i radomszczańskim, obwód wieluński z powiatami wieluńskim i ostrzeszowskim oraz obwód kaliski, w skład którego wchodził powiat warcki. $W$ interesującej nas natomiast części województwa radomskiego powiat opoczyński należał do takiegoż obwodu.

Znacznie bardziej ważące przemiany dokonały się natomiast $\mathrm{w}$ tym czasie w strukturze i hierarchii miejskiej sieci osadniczej regionu. Stało się to za sprawą uprzemysłowienia tej części kraju. Dokonała się ona najpierw dzięki inicjatywie światłych właścicieli prywatnych dóbr, którzy - biorąc przykład z Ozorkowa - zaczęli w nich zakładać włókiennicze, głównie sukiennicze, osady rękodzielnicze. W ten sposób powstawały one kolejno w: Aleksandrowie (1815), Zduńskiej Woli (1816), Strykowie (1820), Konstantynowie (1821) i Tomaszowie (1822). Poza Strykowem zakładano je na gruntach wsi, ale ich dynamiczny rozwój sprawił, że do 1830 r. wszystkie uzyskały prawa miejskie.

Dobry przykład prywatnych osad rękodzielniczych zmobilizował władze królestwa do opracowania ambitnego planu industrializacji kraju i utworzenia sieci „miast fabrycznych” (w rzeczywistości rękodzielniczo-manufakturowych). Co znamienne, większość tych ośrodków miała powstać - ze względu na kierunek napływu nowych osadników - w za146 chodniej części ówczesnego państwa, a więc szczególnie na terenie obecnego naszego regionu. Przemysłowy awans stał się wówczas udziałem szeregu małych miast i wręcz zapyziałych miasteczek rządowych w tej części kraju, w tym Zgierza (1821), Łodzi (1823) i Pabianic (1823). Były też próby urządzenia osad rękodzielniczych lub manufaktur w innych jeszcze miastach rządowych - w Łęczycy, Rawie, Skierniewicach, Przedborzu, Wieluniu i Uniejowie - ale, głównie ze względu na utratę autonomii po powstaniu listopadowym, nie osiągnęły one powodzenia. Likwidacja polskiego wojska, które było głównym odbiorcą sukna na mundury, spowodowała głęboki kryzys rękodzielnictwa wełnianego i w rezultacie upadek wielu osad sukienniczych. Przetrwały tylko te, które zdołały się przestawić, choćby częściowo, na produkcję wyrobów bawełnianych. Były to: Łódź, Zgierz, Pabianice, Ozorków, Konstantynów, Aleksandrów, Zduńska Wola i Tomaszów. Sześć pierwszych z nich wytworzyło z czasem łódzki zespół miejski, który stał się gospodarczym trzonem regionu. Tym samym dokonała się tu niezwykła inwersja antropogeograficzna - w marginalnej dotychczas, wododziałowej, słabo zaludnionej i zapóźnionej w rozwoju części omawianego obszaru ukształtowało się największe skupisko znacznych na owe czasy miast, o dużym i stale wzrastającym potencjale ekonomicznym. Najbardziej dynamicznie rozwijał się zwłaszcza centralny ośrodek tego zespołu - Łódź, która z nędznej mieściny, liczącej w 1820 r. 767 mieszkańców, kolejno powiększała ich liczbę do: 4720 w 1831 r., 10645 
w 1837 r., 15565 w 1850 r. i 32364 w 1862 r., w przededniu wkroczenia na drogę rozwoju wielkoprzemysłowego. Stała się ona wówczas największym miastem regionu, dystansując - także pod względem znaczenia gospodarczego - dawne historyczne stolice księstw, ziem i województw - Łęczycę, Sieradz i Rawę.

Konstytucyjny okres Królestwa Polskiego, nazwany przez Wacława Ostrowskiego „świetną kartą z dziejów planowania w Polsce”, oprócz uprzemysłowienia, zapisał się także chlubnie stworzeniem nowego systemu dróg. Przeprowadzono je, w miarę możliwości, w prostych liniach „od wieży kościoła do wieży kościoła”, a najważniejszą z nich był tzw. trakt fabryczny, wiodący z Warszawy przez Łowicz i Sieradz do Kalisza. System ten przyczynił się do wzmocnienia więzi zarówno wewnątrz-, jak i międzyregionalnych, a dla miast położonych na trasie przebiegu ważniejszych dróg, a zwłaszcza traktu fabrycznego, stworzył dodatkowy impuls rozwoju.

Powstanie "miast fabrycznych" zmieniło również w istotny sposób strukturę etniczną i religijną regionu, zwłaszcza jego centralnej części. Do pracy w nich sprowadzono bowiem "pożytecznych cudzoziemców", tj. specjalistów z branży włókienniczej - tkaczy, prządników, farbiarzy, blicharzy i innych - głównie z krajów niemieckich oraz z Czech. W samej Łodzi w 1831 r. Niemcy stanowili 74,1\% ogółu mieszkańców, a Żydzi, którzy zaczęli stopniowo napływać do miasta 8,5\%. Później struktura sukcesywnie się zmieniała na korzyść ludności polskiej; w 1857 r. Polacy stanowili $43 \%$ mieszkańców Łodzi, Niemcy 41\%, a Żydzi 15\%. Podobne proporcje zanotowano i w innych miastach "fabrycznych". Znaczną część osadników pochodzenia niemieckiego stanowili wyznawcy różnych odłamów protestantyzmu, których odsetek w 1857 r. sięgał aż 41,9\%.

Jeżeli do nowych cudzoziemskich przybyszy osiadłych w miastach "fabrycznych" dodamy niemieckich głównie kolonistów z - licznych szczególnie w okolicach Łodzi - dawnych kolonii olęderskich oraz pruskich, również w większości protestantów, a do tego dodamy liczne skupiska żydowskie, istniejące w prawie wszystkich miastach tego obszaru, a także uwzględnimy niewielką społeczność czeską z Zelowa i okolicznych wsi, wyznania czesko-braterskiego (kalwińskiego), to otrzymamy obraz wielokulturowego regionu, wyróżniającego się pod tym względem w skali całego kraju.

Likwidacja autonomii Królestwa Polskiego po klęsce powstania listopadowego nie pociągnęła za sobą $\mathrm{w}$ pierwszej chwili żadnych zmian w organizacji terytorialnej omawianego obszaru, jeśli nie liczyć przemianowania dotychczasowych województw na gubernie. Stało się to dopiero w 1845 r., gdy nastąpiło połączenie guberni kaliskiej i mazowieckiej w jedną dużą gubernię warszawską; tereny zapiliczańskie weszły wówczas 
w skład guberni radomsko-kieleckiej. Wcześniej, bo w 1842 r., prawa i prerogatywy miasta gubernialnego otrzymała Łódź, co miało jednak znaczenie czysto symboliczne, gdyż nie wiązało się z tym utworzenie odpowiedniej guberni ziemskiej. W $1853 \mathrm{r}$. analogiczny formalny awans stał się też udziałem Piotrkowa. Mimo że były to jedynie puste gesty, to jednak świadczą one dobitnie, że właśnie te dwa miasta zyskały w owym czasie najważniejszą pozycję w regionie. Do awansu Piotrkowa przyczyniło się niewątpliwie jego położenie na trasie wybudowanej w latach 1845-1846 pierwszej w Królestwie linii kolejowej, tzw. warszawsko-wiedeńskiej; Łódź znalazła się poza przebiegiem tej trasy i musiała korzystać z niej za pośrednictwem stacji w Rokicinach, położonej $27 \mathrm{~km}$ od miasta.

Okresem przełomowym w rozwoju regionu - i to zarówno pod względem przemian społeczno-gospodarczych, jak i administracyjnych - stały się lata 60. XIX w. Paradoksalnie, postęp, który się wtedy dokonał, nastąpił mimo traumy po klęsce powstania listopadowego.

Niewątpliwie najważniejszym wydarzeniem społeczno-gospodarczym był dekret carski z 1864 r. o uwłaszczeniu chłopów. W jego wyniku rzesze chłopów, którzy nie byli w stanie wykupić ziemi, ruszyły w poszukiwaniu pracy i lepszego bytu do miast, zwłaszcza przemysłowych, w tym szczególnie do Łodzi, która stała się dla nich przysłowiową ,,ziemią obiecaną". Tym samym miasta te zyskały tanią siłę roboczą i mogły znacznie zdynamizować swój rozwój. Uwłaszczenie chłopów wiązało się jednocześnie z regulacją pouwłaszczeniową wsi. Polegała ona na separacji gruntów chłopskich od dworskich oraz ich komasacji - w miejsce związanych z systemem trójpolowym trzech pól występujących w trzech odrębnych niwach morfologicznych, a także różnych „przydatków” i „przymiarków", każdy gospodarz otrzymywał jeden zwarty zagon ziemi. Regulacja ta zmieniała równocześnie krajobraz większości wsi, gdyż w miejsce dominujących wcześniej wsi-ulicówek, z gęsto zabudowanym siedliskiem, pojawiły się wsie-rzędówki, z zabudową luźno skupioną wzdłuż drogi ciągnącej się $\mathrm{w}$ poprzek całego areału wsi oraz z osobno wydzielonym zespołem dworskim lub folwarkiem. W ślad za regulacją pouwłaszczeniową nastąpiła zmiana w systemie gospodarowania. W miejsce mało wydajnego systemu trójpolowego upowszechnił się bardziej efektywny płodozmian. Wolny chłop, właściciel własnej ziemi, był teraz w stanie wygospodarować nadwyżki rolne, które mógł zbywać w najbliższym mieście. Włączając się w obrót pieniężny, mógł też stać się nabywcą dóbr wyprodukowanych w mieście, przyczyniając się tym samym do jego rozwoju.

Dzięki napływowi taniej siły roboczej większość miast regionu, w tym zwłaszcza przemysłowych, zwiększyło znacznie liczbę swych mieszkańców, rozszerzając równocześnie sferę swej działalności gospodarczej. Szczególnym beneficjentem tych przemian stała się Łódź, która w krót- 
kim czasie zwielokrotniła liczbę swych mieszkańców - 33,5 tys. w 1864 r. do 97 tys. (wliczając w to ludność niestałą) w 1882 r., 283 tys. w 1900 r. i 478 tys. w 1914 r. Do tak dynamicznego rozwoju przyczyniło się także wybudowanie w 1866 r. łącznicy kolejowej do Koluszek, a także przestawienie się przemysłu łódzkiego z produkcji rękodzielniczo-manufakturowej na zmechanizowana, wielkoprzemysłową oraz wielkokapitalistyczyną.

Napływ ludności wiejskiej do miast przemysłowych regionu, a w ślad za nią także biedoty żydowskiej (ale również wielu zamożnych kupców i przedsiębiorców tego pochodzenia) przyczynił się do zauważalnej zmiany struktury narodowościowej ludności. O ile np. w Łodzi w 1864 r. dominowali jeszcze Niemcy (44,3\%), a Polacy i Żydzi stanowili odpowiednio $36,2 \%$ oraz 19,5\% jej mieszkańców, o tyle w 1897 r. sytuacja się odwróciła - Polaków było już 46,4\%, Żydów 29,4\%, a Niemców 21,4\%; ponadto 2,4\% stanowili Rosjanie, których liczba w popowstaniowym „Priwislinskim Kraju" znacznie się zwiększyła, natomiast 0,4\% przypadało na przedstawicieli innych narodowości. Mimo tych zmian, region nasz, a zwłaszcza jego centralna część, utrzymał i nawet bardziej jeszcze zróżnicował swój wielokulturowy - zarówno w sensie etnicznym, jak i wyznaniowym - charakter.

Następnym ważnym wydarzeniem, jakie nastąpiło w latach 60. XIX w., a konkretnie w 1867 r., była kolejna zmiana podziału administracyjnego tych ziem i to na różnych szczeblach ich struktury organizacyjnej. Dokonano wówczas nowego podziału na gubernie, w wyniku którego terytorium naszego obecnego regionu znalazło się, w różnych fragmentach, aż w czterech z nich (ryc. 4). Co zaskakujące, Łódź, która była w tym czasie największym miastem na tym obszarze, nadal nie doczekała się awansu do rangi stolicy jednostki terytorialnej rzędu regionalnego i została podporządkowana Piotrkowowi, który po raz pierwszy doczekał się awansu tej rangi.

Stało się to przypuszczalnie ze względów politycznych - robotnicza Łódź, zaangażowana w powstanie styczniowe, a przy tym pozbawiona urzędów i gmachów publicznych, była z pewnością gorzej postrzegana przez władze carskie od posiadającego bogate tradycje historyczne, mieszczańskiego Piotrkowa.

Gubernia piotrkowska objęła proporcjonalnie największa, centralną i południowo-wschodnią część obecnego regionu i w tych ramach została podzielona na sześć powiatów: rawski, brzeziński, łódzki, łaski, piotrkowski i noworadomski (radomszczański), a dalej rozciągała się aż po Sosnowiec. W powyższym podziale powiatowym zwraca uwagę pojawienie się, po raz pierwszy, dwóch nowych powiatów - łódzkiego i łaskiego. O ile ten pierwszy administracyjny awans Łodzi trudno uznać za satysfakcjonujący, o tyle ustanowienie w Łasku ośrodka nowego powiatu oznaczało dla tego miasta awans realny, a przy tym precedensowy. Stał się on możli- 


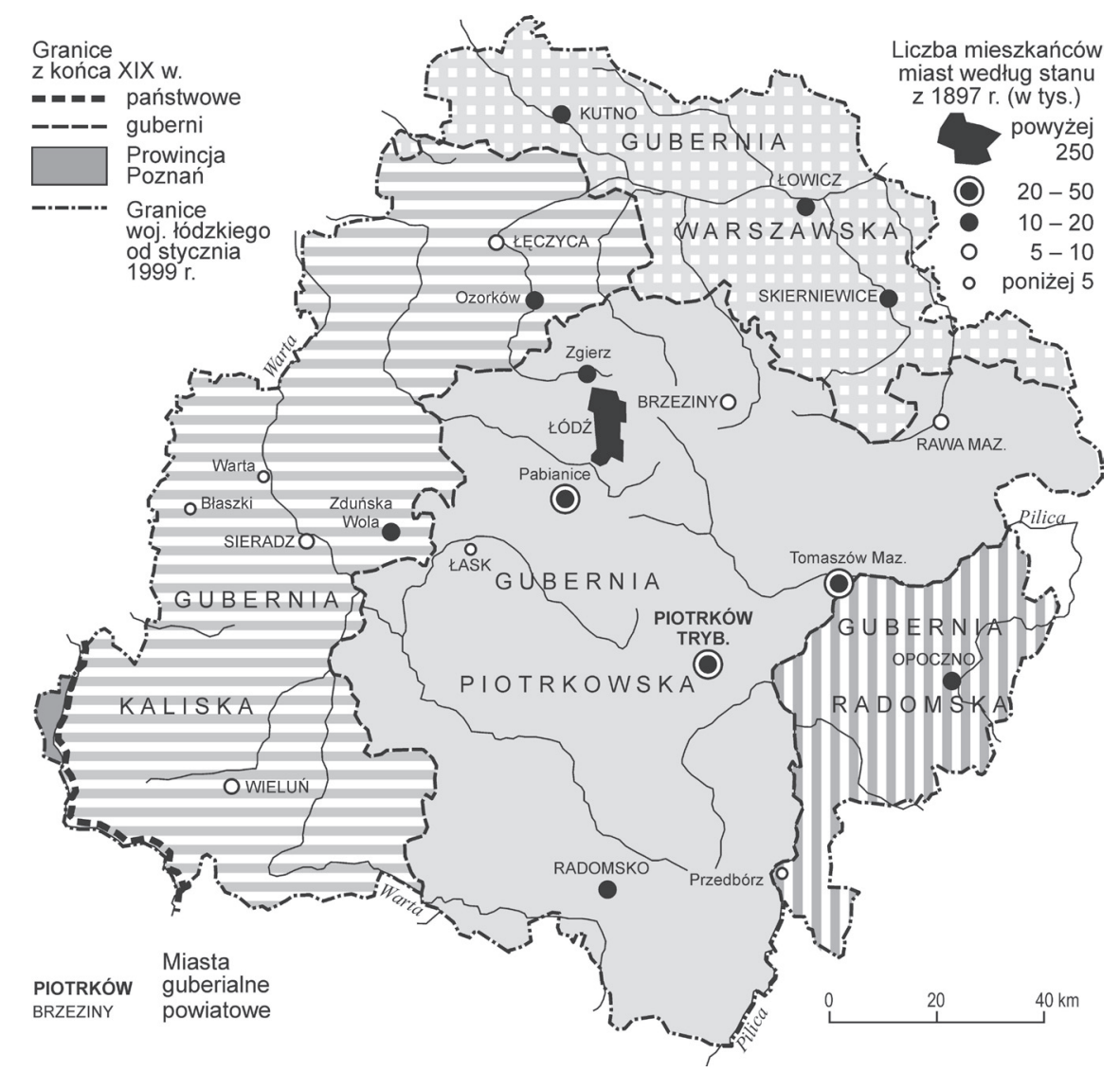

Ryc. 4. Obszar obecnego województwa łódzkiego w rosyjskim podziale gubernialnym po $1867 \mathrm{r}$.

wy dzięki przeprowadzonemu w tym czasie, obok uwłaszczenia chłopów, również uwłaszczeniu mieszczan, w związku z tym przestały formalnie istnieć miasta prywatne. Tym samym powstała możliwość przeprowadzenia takiego podziału na powiaty, aby ich centrami zostały nie tylko dawne miasta rządowe, niekiedy bardzo małe, lecz także większe dawne miasta prywatne. W tym przypadku zyskał Łask, a stracił Szadek.

Zachodnia część naszego obszaru znalazła się w obrębie guberni kaliskiej i w części nas dotyczącej została podzielona na powiaty łęczycki, sieradzki i wieluński, ponadto pas terenu $\mathrm{w}$ rejonie Uniejowa i Warty należał do powiatu tureckiego, a okolice Błaszek do powiatu kaliskiego. Część północna regionu, podzielona na powiaty kutnowski, łowicki i skierniewicki, pozostawała w pomniejszonej guberni warszawskiej. $Z$ kolei tereny zapiliczańskie weszły w skład guberni radomskiej i powiatu opoczyńskiego, a niewielki fragment wokół Przedborza do powiatu koneckiego. 
W uzupełnieniu należy dodać, że wcześniej, bo w 1864 r., nawiązując do reformy pouwłaszczeniowej, utworzono w Królestwie Polskim trzeci szczebel podziału administracyjnego, tzw. gminy zbiorowe, obejmujące po kilka gromad wiejskich oraz obszary dworskie.

Kolejnym etapem porządkowania przez władze carskie organizacji prawno-administracyjnej kraju był ukaz carski z 1869 r. pozbawiający praw miejskich większość zastygłych w rozwoju, maleńkich miasteczek rolniczych, a także kilku nowych miast przemysłowych, które nie zdołały się rozwinąć po upadku sukiennictwa. Spośród około stu miejscowości, które w średniowieczu i później otrzymały prawa miejskie, blisko 40 utraciło je już znacznie wcześniej. Do omawianego okresu status miejski zachowały jednak nadal na naszym terenie 64 miejscowości. Teraz aż 43 z nich tych praw pozbawiono i zostały zdegradowane do rzędu wsi. W porządku alfabetycznym były to: Aleksandrów, Bełchatów, Będków, Białaczów, Biała Rawska, Bielawy, Brzeźnica Nowa, Burzenin, Dąbrowice, Drzewica, Działoszyn, Głowno, Grabów Łęczycki, Grocholice, Inowłódz, Jeżów, Kamieńsk, Kazimierz, Kiernozia, Konstantynów, Krośniewice, Lutomiersk, Lututów, Parzęczew, Piątek, Pławno, Poddębice, Rozprza, Rzgów, Stryków, Sulejów, Szadek, Tuszyn, Ujazd, Uniejów, Widawa, Wieruszów, Wolbórz, Złoczew, Żarnów i Żychlin. Swoje prerogatywy miejskie zachowało jedynie 21 miast, w tym 13 wymienionych wcześniej miast powiatowych, pięć największych miast przemysłowych - Pabianice, Tomaszów, Zduńska Wola, Zgierz i Ozorków, a ponadto Błaszki, Przedbórz oraz Warta.

Opisana wyżej prawno-administracyjna struktura ziem obecnego regionu łódzkiego przetrwała już w tej formie, bez istotnych zmian, aż do czasu pierwszej wojny światowej.

Okres drugiej połowy XIX i początków XX w. zaznaczył się znacznym zdynamizowaniem rozwoju gospodarczego regionu. Stał się on wówczas jednym $z$ największych okręgów przemysłu włókienniczego w Europie, zatrudniając w tej branży ponad 80 tys. pracowników. W samej tylko Łodzi pracowało ponad 50\% robotników przemysłu włókienniczego w Królestwie, w 1900 r. liczyła ona już 283 tys. mieszkańców (a w 1914 r. 478 tys.). Na drogę wielkoprzemysłowego rozwoju wkroczyły także Pabianice, w których oprócz dużych zakładów bawełnianych powstał również przemysł chemiczny. W 1900 r. liczyły one już 26,8 tys. mieszkańców. Zgierz, Tomaszów i Zduńska Wola również przekroczyły 20 tys., a Ozorków 11,5 tys. Nastąpiła wówczas także dywersyfikacja produkcji przemysłowej. W Piotrkowie, drugim co do wielkości mieście regionu, liczącym wówczas ponad 30 tys. mieszkańców, rozwinęło się np. na dużą skalę hutnictwo szkła, w Radomsku (ok. 15 tys.) przemysł meblarski, w Kutnie (ok. 11 tys.) fabryka maszyn rolniczych, w Sulejowie zakłady wapiennicze, podobnie jak w Opocznie, gdzie ponadto powstały zakłady 
ceramiczne, a Drzewica zasłynęła z wyrobów metalowych. Powszechnie rozwijał się też różnorodny przemysł spożywczy, w tym m.in. duże cukrownie w okolicach Kutna.

Ważną rolę w kształtowaniu się więzi regionalnych odegrał w tym czasie rozwój infrastruktury kolejowej. W 1861 r. istniejące od 1846 r. odgałęzienie od kolei warszawsko-wiedeńskiej ze Skierniewic do Łowicza przedłużono przez Kutno do Bydgoszczy, a w latach 1884-1885, w przedłużeniu łącznicy z Łodzi Fabrycznej do Koluszek, poprowadzono linię kolejową przez Tomaszów i Opoczno do Skarżyska. Wreszcie, w latach 1901-1903, wybudowano bardzo ważną dla regionu, a w założeniu strategiczna, linię kolei warszawsko-kaliskiej, prowadzącą przez Łowicz, Zgierz, Łódź, Pabianice, Zduńską Wolę i Sieradz, aż do graniczącego z zaborem pruskim Kalisza. Ponadto, już na początku XX w., zbudowano kilka linii kolejek wąskotorowych - z Piotrkowa do Sulejowa, ze Zgierza do Krośniewic, z Łodzi do Tuszyna oraz z Rogowa do Rawy (przedłużoną już w czasie pierwszej wojny światowej do Białej Rawskiej). Ważną również rolę, szczególnie dla konsolidacji łódzkiego zespołu miejskiego, odgrywała wybudowana na początku XX w. sieć podmiejskich linii tramwajowych, łączących Łódź ze Zgierzem, Pabianicami, Tuszynem, Konstantynowem i Aleksandrowem (powiększona już w okresie międzywojennym o odcin-

152 ki Zgierz-Ozorków oraz Konstantynów-Lutomiersk).

\section{Między dwoma światowymi wojnami}

Tereny obecnego regionu łódzkiego były w początkowej fazie pierwszej wojny światowej areną bardzo intensywnych działań wojennych. Szczególnie zawzięte działania, związane z tzw. operacją łódzką, toczyły się na południe od Łodzi, a następnie w czasie wielomiesięcznych walk pozycyjnych na linii Bzura-Pilica. W trakcie tych ostatnich prawie całkowicie została zniszczona Rawa, a bardzo poważnych zniszczeń doznały także Inowłódz, Skierniewice i Bolimów; znacznie ucierpiały też inne miasta i miejscowości na trasie głównej ofensywy oraz w strefie walk pozycyjnych. W wyniku działań wojennych, zniszczeń oraz ucieczki ludności, wiele miast regionu poniosło duży uszczerbek w stanie zaludnienia, np. Łódź wraz z przedmieściami straciła ok. 260 tys. osób, tj. 43\% ogółu mieszkańców; proporcjonalnie duże straty ludnościowe poniosły też: Wieruszów, Konstantynów, Brzeziny, Rawa i inne.

Po ostatnim zajęciu przez Niemców zachodniej i centralnej części naszego obszaru władze okupacyjne powołały 19 grudnia $1914 \mathrm{r}$. gubernię łódzka, w skład której weszły powiaty: łódzki, brzeziński i łaski; na jej czele postawiono Cesarskoniemieckie Wojenne Gubernatorstwo w Łodzi. 
Tak więc to okupacji niemieckiej Łódź zawdzięcza po raz pierwszy awans do rangi ośrodka administracyjnego szczebla regionalnego, a właściwie - biorąc pod uwagę ograniczony zasięg terytorialny nowej guberni - raczej subregionalnego. Od jesieni 1915 r. cały ten obszar znalazł się zresztą w poszerzonej niemieckiej strefie okupacyjnej, dla której utworzono nową strukturę w postaci Generalnego Gubernatorstwa Warszawskiego.

Wydanie przez władze niemieckie aktu z 5 listopada 1916 r., zapowiadającego utworzenie z Królestwa monarchii konstytucyjnej związanej z państwami centralnymi, zapoczątkowało proces budowy polskich struktur życia politycznego, co zaowocowało po uzyskaniu przez kraj niepodległości.

Pierwsze lata odrodzonej Rzeczypospolitej nie były okresem odpowiednim dla radykalnych zmian wewnętrznej struktury organizacji terytorialnej państwa. Nadal bowiem toczyły się walki o jego kształt i granice, trudno też było mówić o pełnej integracji wewnętrznej dopiero co zlepionych ze sobą tak różnych od siebie zaborów, działających od ponad stu lat $\mathrm{w}$ ramach odmiennych form prawno-ustrojowych, a także społeczno-gospodarczych. Toteż pierwszy podział administracyjny Polski na województwa, przeprowadzony w 1919 r., został dokonany w ramach dawnych podziałów rozbiorowych, tj. wpisując się w zlikwidowane zaledwie rok wcześniej granice państw zaborczych według stanu z $1914 \mathrm{r}$. Utworzone wówczas województwo łódzkie - po raz pierwszy w skali odpowiadającej randze Łodzi - siłą rzeczy w tej sytuacji zostało wkomponowane w układ dawnych guberni. Powstało ono z połączenia uprzednich guberni kaliskiej i piotrkowskiej, w przypadku tej drugiej pomniejszonej o powiat rawski, który wszedł do województwa warszawskiego, oraz o tereny od Częstochowy do Sosnowca, włączone do województwa kieleckiego (ryc. 5). $\mathrm{W}$ podziale wewnętrznym obejmowało ono osiem dawnych powiatów „kaliskich” (w zasadzie bez zmian terytorialnych), a mianowicie powiaty: wieluński, sieradzki, łęczycki, turecki, kaliski, kolski, koniński i słupecki oraz pięć byłych powiatów „piotrkowskich" - łaski, łódzki, brzeziński, piotrkowski i radomszczański. Obecne północne części naszego regionu, tj. powiaty kutnowski, łowicki i skierniewicki, oraz wspomniany już rawski znalazły się w ramach województwa warszawskiego.

Zasięg i kształt tego pierwszego województwa łódzkiego, z jego nienaturalnym wydłużeniem z południowego wschodu na północny zachód, był niewątpliwie w dużej mierze sztuczny. $Z$ tak odległymi, sięgającymi po ujście Prosny do Warty, częściami historycznej Wielkopolski zarówno ani tradycyjny „łęczycki” trzon regionu, ani sama Łódź nie wykształciły ściślejszych więzi emocjonalnych ani funkcjonalnych, co wynikało m.in. z silnej w przeszłości w tym rejonie regionalnej rangi Kalisza. Nienaturalne było ponadto peryferyjne względem podległego jej obszaru położenie 


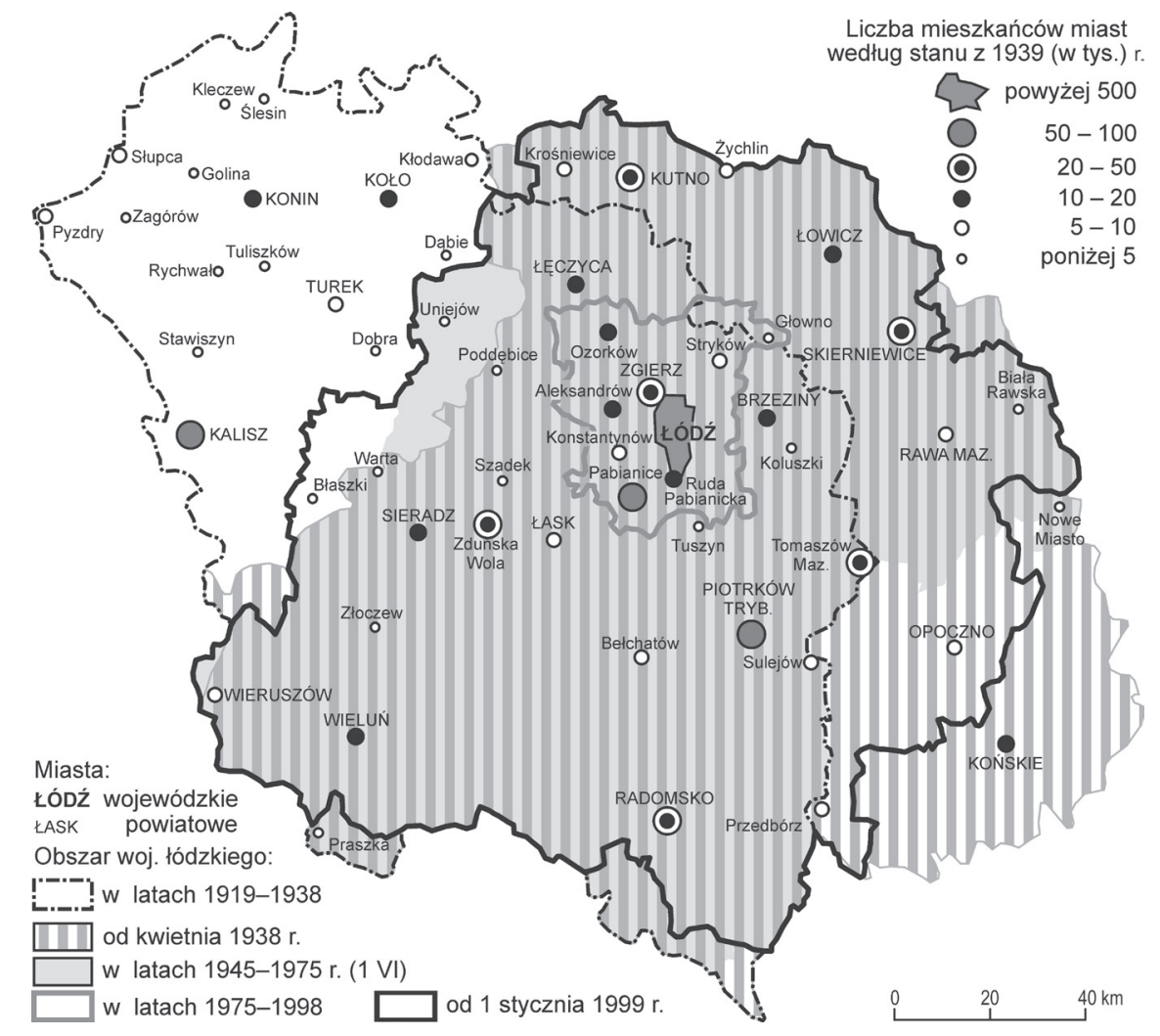

Ryc. 5. Zmiany podziału administracyjnego województwa łódzkiego w okresie międzywojennym i powojennym $(1919,1938,1950)$

Łodzi jako stolicy województwa w odległości zaledwie 25-30 km od granic województwa warszawskiego, do którego należało Głowno, podczas gdy do najdalszych krańców własnego województwa $-\mathrm{z}$ jednej strony Koniecpola, z drugiej Słupcy - miała ona w linii prostej po ponad $120 \mathrm{~km}$.

Zniszczenia i straty wojenne, grabież przez okupanta urządzeń fabrycznych i surowców, wojna z bolszewikami i utrata tradycyjnych wschodnich rynków zbytu, a także depozytów w dawnych bankach rosyjskich, a następnie światowy kryzys gospodarczy - wszystko to ograniczało w znacznym stopniu rozwój regionu w dwudziestoleciu międzywojennym, szczególnie w dziedzinie produkcji przemysłowej. Liczącym się osiągnięciem w tym okresie była jedynie rozbudowa sieci kolejowej. Sztandarową inwestycja, ułatwiającą eksport polskiego węgla, stała się budowa w latach 1930-1933 magistrali Śląsk-Gdynia, która na naszym terenie przebiegała od Trębaczewa przez Karsznice, Szadek i Poddębice aż po Świnice Warckie. Zbudowano także od podstaw w 1926 r. linię z Czę- 
stochowy przez Wieluń i Wieruszów do Kępna, jak również przedłużono, już w 1921 r., trasę Łowicz-Kutno aż do Poznania, łącząc tym samym główne miasta dawnych zaborów - rosyjskiego i pruskiego - poprzez były kordon graniczny; także Łódź uzyskała połączenie z tą trasą dzięki budowie w 1925 r. jednotorowej linii przez Zgierz i Łęczycę do Kutna. Inną istotną zmianą było przywrócenie praw miejskich aż 14 miastom, zabranych im przez zaborcę w 1869 r. Były to: Aleksandrów, Bełchatów, Biała Rawska, Głowno, Konstantynów, Krośniewice, Poddębice, Stryków, Sulejów, Tuszyn, Uniejów, Wieruszów, Złoczew oraz Żychlin. W 1923 r. prawa miejskie otrzymała ponadto Ruda Pabianicka. Tym samym liczba miast $\mathrm{w}$ regionie podwoiła się i wzrosła do 37.

Dopiero w drugiej połowie lat 30. XX w. nastąpiło ożywienie gospodarcze, które sprzyjało również integracji wewnętrznej kraju. Wtedy też uznano, że zaistniały wreszcie warunki, aby w podziale administracyjnym przełamać relikty granic zaborczych i zjednoczyć w ramach województw rozdzielone przez ponad stulecie dawne dzielnice historyczne. Nowy podział administracyjny na szczeblu województw wprowadzono na mocy ustawy z 1 kwietnia 1938 r. (ryc. 5). Oddzielono wówczas od województwa łódzkiego pięć powiatów zachodnich - kaliski, kolski, turecki, koniński i słupecki - które weszły w skład województwa poznańskiego, odtwarzającego tym samym w głównych zarysach zasięg historycznej Wielkopolski. Jednocześnie przyłączono do niego dwa powiaty zapiliczańskie - opoczyński i konecki - należące uprzednio do województwa kieleckiego oraz cztery powiaty wyłączone z zachodniej części województwa warszawskiego - kutnowski, łowicki, skierniewicki i rawski.

W wyniku powyższych zmian województwo łódzkie otrzymało bardziej zwarty kształt, a Łódź znalazła się w jego obrębie w bardziej centralnym położeniu. Ponadto w najpełniejszy, jak dotychczas, sposób nawiązało ono do pierwowzoru terytorialnego zasięgu wczesnośredniowiecznej ziemi i księstwa łęczyckiego (sprzed jego podziału), z jednym tylko wyjątkiem - nie objęło ono powiatu tureckiego (wówczas jeszcze wraz z Uniejowem), którego teren od najdawniejszych czasów był integralną częścią pierwotnej prowincji łęczyckiej. Z kolei przyłączenie czterech powiatów mazowieckich, choć pozbawione podstaw historycznych, miało uzasadnienie funkcjonalne, gdyż co najmniej od połowy XIX w. zaczęły one realnie ciążyć do łódzkiego okręgu przemysłowego. Tym samym nowy kształt województwa można uznać za prawie optymalny, odpowiadający realnemu zasięgowi oddziaływania Łodzi. Jego zaś konotacje z prowincją historyczną upoważniają do uznania go za prawdziwy region, jedynie ze zmienionym centrum i nazwę w stosunku do pierwowzoru.

Wybuch drugiej wojny światowej przerwał brutalnie proces konsolidowania się regionu łódzkiego w jego nowych granicach. Tuż po opanowaniu 
kraju władze hitlerowskie dokonały własnego podziału okupowanych terenów. W jego wyniku region łódzki został rozdarty pomiędzy dwa odrębne twory polityczne. Zachodnia jego część, tj. powiaty: kutnowski, łęczycki, łódzki, łaski, sieradzki i wieluński oraz zachodnie fragmenty brzezińskiego, piotrkowskiego i radomszczańskiego zostały wcielone do tzw. Kraju Warty (Wartheland), włączonego bezpośrednio do Trzeciej Rzeszy, i podlegały intensywnej germanizacji. Pozostałe, wschodnie części regionu weszły natomiast w skład tzw. Generalnego Gubernatorstwa, mającego status swego rodzaju kolonii administrowanej przez Niemców.

\section{Region łódzki w strukturach administracyjnych PRL i III Rzeczypospolitej}

W pierwszej fazie agresji hitlerowskiej na Polskę ogromnych zniszczeń doznały szczególnie miasta położone w zachodniej części naszego regionu - Wieluń, Wieruszów, Złoczew, Szczerców, Widawa, Sieradz i Uniejów, a także miejscowości leżące w strefie walk nad Bzurą - Łęczyca, Kutno, Łowicz i inne. Natomiast w trakcie ofensywy radzieckiej w styczniu 1945 r. najbardziej ucierpiały miejscowości nadpiliczańskie - Inowłódz, Sulejów,

156 Przedbórz oraz Radomsko. Szczęśliwie w obu przypadkach z nawałnicy wojennej w miarę bez zniszczeń wyszły przemysłowe miasta regionu. Znacznie boleśniejsze od zniszczeń okazały się jednak straty ludnościowe, które niekiedy przybrały rozmiary katastrofy demograficznej. Dotyczyło to w szczególności małych miast, zamieszkanych uprzednio, często w większości, przez ludność żydowską, która uległa eksterminacji. Z kolei w ostatniej fazie wojny nastąpił exodus ludności niemieckiej, z dawna tu osiadłej, ale w części splamionej współpracą z okupantem. Jeżeli do tego dodamy straty ludności polskiej, to uświadomimy sobie skalę depopulacji regionu, głównie w odniesieniu do miast. Dla przykładu, Łódź licząca w 1939 r. 672 tys. mieszkańców, w 1945 r. miała ich tylko 502 tys., Zduńska Wola zmniejszyła swój stan zaludnienia odpowiednio z 25,3 tys. do 14,6 tys., Zgierz stracił ok. 6 tys. mieszkańców, Piotrków i Aleksandrów po ok. 5 tys.; podobnie było $\mathrm{w}$ innych miastach.

Okres PRL, mimo licznych deformacji w sferze życia społeczno-politycznego oraz błędów w systemie zarządzania gospodarką narodową, przyczynił się obiektywnie do odbudowy i dalszego rozwoju regionu. Dotyczyło to zwłaszcza dziedziny przemysłu (m.in. budowy kopalni węgla brunatnego i elektrowni w Bełchatowie), ale także infrastruktury komunikacyjnej (znana "gierkówka” z Katowic do Warszawy i magistrala kolejowa z Górnego Śląska przez Opoczno do aglomeracji warszawskiej), innych dziedzin zagospodarowania przestrzennego oraz przyspieszonej 
urbanizacji regionu. $Z$ braku miejsca nie możemy sobie pozwolić na szersze omówienie tych zagadnień, powszechnie zresztą dość dobrze znanych. Z konieczności ograniczymy się do zobrazowania procesu przemian terytorialno-administracyjnych naszego regionu, zarówno w okresie PRL, jak i współczesnej III Rzeczypospolitej.

Po wyzwoleniu, formalnie aktem z 28 czerwca 1946 r., zostało odtworzone województwo łódzkie w granicach z 1938 r., z tą jedynie zmiana, że w uzupełnieniu do istniejących wcześniej powiatów ziemskich stworzono także, dla tzw. miast wydzielonych, tj. Piotrkowa Trybunalskiego, Tomaszowa Mazowieckiego, Pabianic i Zgierza, powiaty grodzkie. Już jednak w cztery lata później, w 1950 r., dokonano korekty tego podziału, w wyniku której województwo łódzkie zostało pomniejszone o dwa powiaty zapiliczańskie oraz gminę Koniecpol, które przeszły do województwa kieleckiego (ryc. 5).

Do kolejnych korekt podziału administracyjnego, tym razem głównie o charakterze wewnętrznym, doszło w latach 1954-1956. Utworzono wówczas, wycinając z wcześniej istniejących, cztery nowe powiaty, a mianowicie: bełchatowski, pajęczański, wieruszowski oraz poddębicki, dołączając do tego ostatniego gminę Uniejów z województwa poznańskiego, co nieznacznie powiększyło obszar województwa łódzkiego.

Do radykalnej zmiany podziału administracyjnego Polski doszło w 1975 r., kiedy to w miejsce dotychczasowych 17 dużych województw ustanowiono 49 małych, likwidując jednocześnie szczebel powiatowy. Podział ten brutalnie rozbił jedność regionu łódzkiego, rozczłonkowując go aż na osiem części (ryc. 6). W całości z terytorium dawnego województwa wykrojono dwa nowe małe - kadłubkowe województwo miejskie łódzkie, obejmujące praktycznie tylko aglomerację łódzka, oraz województwo sieradzkie. Dwa kolejne - piotrkowskie i skierniewickie - oprócz wschodnich części rodzimego regionu objęły także znaczne tereny $z$ dawnych sąsiednich województw - pierwsze były powiat opoczyński z kieleckiego, a drugie powiaty żyrardowski i sochaczewski z warszawskiego. Pozostałe części naszego regionu weszły w skład obrzeżnych nowych województw. I tak południowe fragmenty dawnych powiatów radomszczańskiego i pajęczańskiego włączono do województwa częstochowskiego, dawny powiat wieruszowski do kaliskiego, zachodnie gminy z powiatów poddębickiego i łęczyckiego do konińskiego i wreszcie pozostałą część łęczyckiego oraz były powiat kutnowski do województwa płockiego.

Nowy podział rozbił na dwie dekady integralność terytorialną regionu łódzkiego, obniżając przy tym wydatnie regionotwórczą rolę Łodzi, zdegradowaną do rangi stolicy najmniejszego w kraju miniwojewództwa, nieobejmującego nawet całości łódzkiego zespołu miejskiego. Pozbawił on także rangi ośrodków administracyjnych średniego stopnia 12 dawnych 


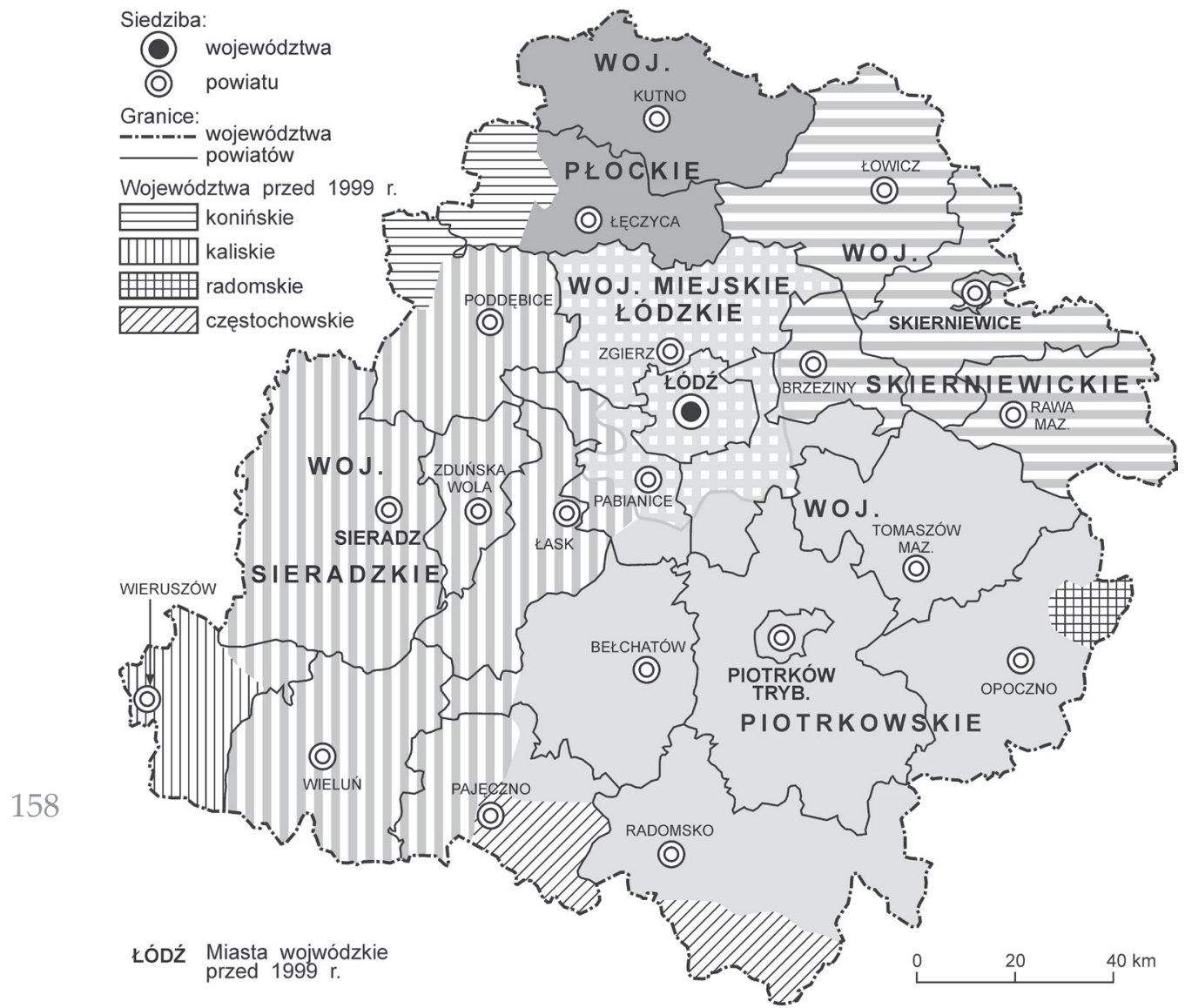

Ryc. 6. Obszar obecnego województwa łódzkiego w podziale administracyjnym z 1975 r. na tle współczesnych jego granic

miast powiatowych, przyznając jednocześnie awans o szczebel wyżej, trzem pozostałych z nich. Pozyskanie funkcji wojewódzkich przez Piotrków, Sieradz i Skierniewice przyczyniło się niewątpliwie do wzrostu ich znaczenia w sieci osadniczej, a także do ukształtowania się silniejszych więzi subregionalnych w ich otoczeniu.

Dekomunizacja Polski w 1989 r. i utworzenie III Rzeczypospolitej zdekomponowały na pewien czas, scentralizowany dotychczas, system gospodarczy kraju i regionu, osłabiając go nawet przejściowo. Nie była to zatem pora sprzyjająca wprowadzaniu racjonalnych zmian administracyjnych. Przeprowadzono je dopiero 10 lat później. Nowy podział Polski z 1 stycznia 1999 r. przywrócił duże województwa. W przypadku województwa łódzkiego nawiązywało ono w ogólnych zarysach do kształtu i zasięgu poprzednika z 1938 r., pomniejszonego jedynie o powiat konecki 
Historyczno-geograficzne podstawy oraz proces kształtowania się regionu...

i gminę Koniecpol od strony południowo-wschodniej oraz gminę Praszka, która przeszła do Opolszczyzny, powiększonego natomiast po stronie zachodniej o gminy: Uniejów, Goszczanów, Błaszki i Brąszewice. W podziale wewnętrznym przywrócono dawne powiaty w zmienionych nieco kształtach, gdyż samorządowe gminy (uzyskały one samorząd jeszcze przed reformą wojewódzką) mogły same deklarować przynależność do wybranego powiatu, co w większości przypadków zostało zaakceptowane. W wyniku tych deklaracji ustanowiono też dwa nowe powiaty - pabianicki i zduńskowolski, a kosztem północnej części powiatu łódzkiego reaktywowano powiat zgierski, z południowo-wschodniej natomiast utworzono łódzki wschodni.

Nowy zasięg i struktura wewnętrzna województwa łódzkiego, powstałe po raz pierwszy nie w wyniku arbitralnych decyzji, lecz z uwzględnieniem interesów oraz ciążeń poszczególnych gmin, wydaje się najbardziej optymalny z dotychczas istniejących, odpowiadający rzeczywistemu zasięgowi oddziaływania Łodzi. Samorządowy charakter wszystkich trzech szczebli organizacji terytorialnej regionu stworzył tu nową jakość w sferze społecznej, gospodarczej i politycznej, umacniając zarówno więzi lokalne, jak i regionalne.

\section{Literatura}

Arnold S. (1927), Terytoria plemienne w ustroju administracyjnym Polski Piastowskiej (wiek XIIXIII), „Prace Komisji dla Atlasu Historycznego Polski”, z. 2.

Atlas historyczny Polski. Województwo sieradzkie i województwo tęczyckie w drugiej połowie XVI w. (1998), cz. 1: Mapy, plany, Instytut Historii PAN, Warszawa.

Banasiak B., Kupisz K., Welfe W. [red.] (1970), Łódź i ziemia łódzka w badaniach Uniwersytetu Łódzkiego w latach 1945-1970, UŁ, Łódź.

Bandurka M. (1995), Zmiany administracyjne i terytorialne ziem województwa łódzkiego w XIX $i X X$ w., Archiwum Państwowe w Łodzi, Łódź.

Baranowski B. (1970), Struktura gospodarcza regionu łęczycko-sieradzko-wieluńskiego w XVIXVIII w., "Zeszyty Naukowe Uniwersytetu Łódzkiego”, Ser. I, z. 72.

Baranowski B. (1979), Ziemia piotrkowska do końca XVIII w., [w:] Z. Stankiewicz (red.), Województwo piotrkowskie. Monografia regionalna. Zarys dziejów, obraz wspótczesny, perspektywy rozwoju, Uniwersytet Łódzki, Łódź-Piotrków Trybunalski.

Bochińska J., Zawadzka J. (1999), Polska. Nowy podział terytorialny, Świat Książki, Warszawa.

Chojnicki Z., Czyż T. (1993), Region i regionalizacja w geografii, [w:] K. Handke (red.), Region, regionalizm - pojęcia i rzeczywistość, Slawistyczny Ośrodek Wydawniczy, Warszawa.

Dejna K. (1973), Dialekty polskie, Ossolineum, Wrocław.

Dylik J. (1947), Indywidualność geograficzna okolic Łodzi, „Czasopismo Geograficzne”, t. 18, z. $1-4$.

Dylik J. (1971), Wojezoództwo ze stolica bez antenatów, Łódzkie Towarzystwo Naukowe, Łódź.

Dzieciuchowicz J. (1998), Ludność Polski Środkowej: procesy i struktury przestrzenne, [w:] A. Werwicki (red.), Transformacja społeczno-ekonomiczna Polski Środkowej, Wyd. Uniwersytetu Łódzkiego, Łódź. 
Jewtuchowicz A., Suliborski A. [red.] (2002), Struktury i procesy ksztattujące tódzki region społeczno-gospodarczy, Wyd. Uniwersytetu Łódzkiego, Łódź.

Koter M. (1961), Terytorium dzisiejszego województwa łódzkiego na mapach Polski z XVI i XVII w., „Rocznik Łódzki”, t. 5.

Koter M. (1999), Historyczne uwarunkowania powstania i rozwoju regionu łódzkiego, [w:] A. Dębska-Adamczyk (red.), Ziemia łódzka, Marrow SA, Łódź.

Koter M., Liszewski S., Suliborski A. (1999), Łódź i region Polski Środkowej, Łódzkie Towarzystwo Naukowe, Łódź.

Koter M., Liszewski S., Suliborski A., Wieczorek T. (2002), Łódź i województwo, Łódzkie Towarzystwo Naukowe, Łódź.

Kulesza M. (2001), Morfogeneza miast na obszarze Polski Środkowej w okresie przedrozbiorowym. Dawne województwa łęczyckie i sieradzkie, Wyd. Uniwersytetu Łódzkiego, Łódź.

Kulesza M., Koter M. (1998), Kształtowanie się sieci miast na obszarze Polski Środkowej, [w:] A. Werwicki (red.), Transformacja społeczno-ekonomiczna Polski Środkowej, Wyd. Uniwersytetu Łódzkiego, Łódź.

Kwaśniewski K. (1993), Regionalizacja i regionalizm a podział administracyjny, [w:] M. Latoszek (red.), Regionalizm jako folklor, ruch społeczny $i$ formuła ideologiczno-polityczna, Gdańskie Towarzystwo Naukowe, Gdańsk.

Lalik T. (1967), Organizacja grodowo-prowincjonalna w Polsce XI i początków XII w., „Studia z Dziejów Osadnictwa", t. 5.

Liszewski S. [red.] (2001), Zarys monografii województwa łódzkiego, [w:] Funkcja regionalna Łodzi i jej rola w podnoszeniu konkurencyjności regionów, Wyd. Akademii Ekonomicznej we Wrocławiu, Wrocław.

Missalowa G. (1964), Studia nad powstaniem Łódzkiego Okręgu Przemysłowego 1815-1870, t. 1: Przemyst, Wydawnictwo Łódzkie, Łódź.

Miszczuk A. (2003), Regionalizacja administracyjna III Rzeczypospolitej. Koncepcje teoretyczne a rzeczywistość, Wyd. Uniwersytetu Marii Curie-Skłodowskiej, Lublin.

Ostrowski W. (1949), Świetna karta z dziejów planowania w Polsce: 1815-1830, Towarzystwo Urbanistów Polskich, Warszawa.

Piskozub A. (1968), Gniazdo Orła Białego, PAX, Warszawa.

Piskozub A. (1987), Dziedzictwo polskiej przestrzeni. Geograficzno-historyczne podstawy struktur przestrzennych Polski, Zakład Narodowy im. Ossolińskich, Wrocław.

Rosin R. (1970), Rozwój terytorialno-administracyjny województwa i historycznych ziem wchodzacych w jego skład, [w:] R. Rosin, Łódzkie. Rozwój województwa w Polsce Ludowej, PWN, Łódź.

Rosin R. (1977), Rozwój terytorialno-administracyjny, [w:] J. Śmiałowski (red.), Szkice z dziejów Sieradzkiego, PWN, Łódź.

Rykała A. [red.] (2014), Krajobrazy (regiony) historyczno-polityczne, „Studia z Geografii Politycznej i Historycznej", t. 3.

Samsonowicz H., Wyczański A., Tazbir J., Staszewski J., Kilzwalter T., Nałęcz T., Paczkowski A., Chwalba A. (2007), Historia Polski, t. 1-2, Wydawnictwo Naukowe PWN, Warszawa.

Siuchniński M. [red.] (1965-1967), Miasta polskie w tysiącleciu, t. 1-2, Zakład Narodowy im. Ossolińskich - Wydawnictwo, Wrocław.

Sobczyński M., Kulesza M. (1996), Powiat w polskiej tradycji podziału terytorialnego kraju, Wyd. Uniwersytetu Łódzkiego, Łódź.

Stebelski A. (1928), Przeszłość administracyjna ziem województwa łódzkiego, „Rocznik Oddziału Łódzkiego PTH", t. 1.

Straszewicz L. [red.] (1965), Atlas wojezoództwa łódzkiego, PPWK, Warszawa. 
Historyczno-geograficzne podstawy oraz proces kształtowania się regionu...

Straszewicz L. (1967), Województwo łódzkie. Zarys geograficzno-ekonomiczny, PWN, Warszawa. Trzebiński W., Borkiewicz A. (1956), Podziały administracyjne Królestwa Polskiego 1815-1918 (zarys historyczny), „Dokumentacja Geograficzna”, z. 4.

Werwicki A. [red.] (1998), Transformacja społeczno-ekonomiczna Polski Środkowej, Wyd. Uniwersytetu Łódzkiego, Łódź.

Zajączkowski S. (1951), Studia nad terytorialnym formowaniem się ziemi łęczyckiej i sieradzkiej, Łódzkie Towarzystwo Naukowe, Łódź.

Marek Koter, prof. dr hab., profesor emerytowany, Katedra Geografii Politycznej i Studiów Regionalnych, Uniwersytet Łódzki 